\title{
Some Examples of the Use of Molecular Markers for Needs of Basic Biology and Modern Society
}

\author{
Yuri Phedorovich Kartavtsev
}

check for updates

Citation: Kartavtsev, Y.P. Some Examples of the Use of Molecular Markers for Needs of Basic Biology and Modern Society. Animals 2021, 11, 1473. https://doi.org/10.3390/ ani11051473

Academic Editor:

Athanasios Exadactylos

Received: 15 April 2021

Accepted: 15 May 2021

Published: 20 May 2021

Publisher's Note: MDPI stays neutral with regard to jurisdictional claims in published maps and institutional affiliations.

Copyright: (C) 2021 by the author. Licensee MDPI, Basel, Switzerland. This article is an open access article distributed under the terms and conditions of the Creative Commons Attribution (CC BY) license (https:/ / creativecommons.org/licenses/by/ $4.0 /)$.
A.V. Zhirmunsky National Scientific Center of Marine Biology, Far Eastern Branch, Russian Academy of Sciences, 690041 Vladivostok, Russia; yuri.kartavtsev48@hotmail.com

Simple Summary: The main issues of the report are focused on four items. (1) A combination of nDNA and mtDNA markers best suits the hybrid identification and estimates of genetic introgression between different biological species. (2) The available facts on nDNA and mtDNA diversity seemingly make obvious the introgression presence among many taxa, although, it is evident that introgression may be quite restricted or asymmetric, thus holding at least the "source" taxon (taxa) intact. (3) If we accept that sexually reproducing species in marine and terrestrial realms are introgressed, as it is still evident for many cases, then we should recognize that the biological species concept, in terms of complete lack of gene flow among species, is inadequate due to the fact, that many zoological species are not biological species yet. However, vast modern molecular data proved that with time they definitely become biological species. (4) The recent investigation of fish taxa divergence using central DNA barcoding database shows that most gene trees are, basically, appeared monophyletic and interspecies reticulations are rare.

Abstract: Application of molecular genetic markers appeared to be very fruitful in achieving many goals, including (i) proving the theoretic basements of general biology and (ii) assessment of worldwide biodiversity. Both are provided in the present meta-analysis and a review as the main signal. One of the basic current challenges in modern biology in the face of new demands in the 21st century is the validation of its paradigms such as the synthetic theory of evolution (STE) and biological species concept (BSC). Another of most valuable goals is the biodiversity assessment for a variety of social needs including free web-based information resources about any living being, renovation of museum collections, nature conservation that recognized as a global project, iBOL, as well as resolving global trading problems such as false labeling of species specimens used as food, drug components, entertainment, etc. The main issues of the review are focused on animals and combine four items. (1) A combination of nDNA and mtDNA markers best suits the identification of hybrids and estimation of genetic introgression. (2) The available facts on nDNA and mtDNA diversity seemingly make introgression among many taxa obvious, although it is evident, that introgression may be quite restricted or asymmetric, thus, leaving at least the "source" taxon (taxa) intact. (3) If we consider sexually reproducing species in marine and terrestrial realms introgressed, as it is still evident in many cases, then we should recognize that the BSC, in view of the complete lack of gene flow among species, is inadequate because many zoological species are not biological ones yet. However, vast modern molecular data have proven that sooner or later they definitely become biological species. (4) An investigation into the fish taxa divergence using the BOLD database shows that most gene trees are basically monophyletic and interspecies reticulations are quite rare.

Keywords: mtDNA; nDNA; DNA barcoding; genetic introgression; species fate; molecular evolution; reticulation; gene tree; Neo-Darwinism

\section{Introduction}

DNA barcoding as a common name of the worldwide initiative, iBOL has been used in biology since 2003 [1,2] (iBOL, the international barcode of life project; www.ibol.org, 
accessed on 7 August 2020). However, the origin and the application of the approach based on the variability of biological macromolecules, e.g., to systematics and evolutionary biology have a long history [3-8]. In general, biological molecular markers (MMs) have found numerous applications to satisfy a variety of needs in modern society. The study and use of MMs have already become a new branch of biomedical science, as evidenced by the establishment of special journals (International Journal of Biological Macromolecules, The Journal of Molecular Diagnostics, Biomarkers, Journal of Current Biomarker Findings, Biomarker Insights, DNA barcodes, etc.). MMs are used in many fields of biology and medicine. Below are the three most important for the subject of this paper; general schedule for DNA barcoding also depicted for convenience (Figure 1).

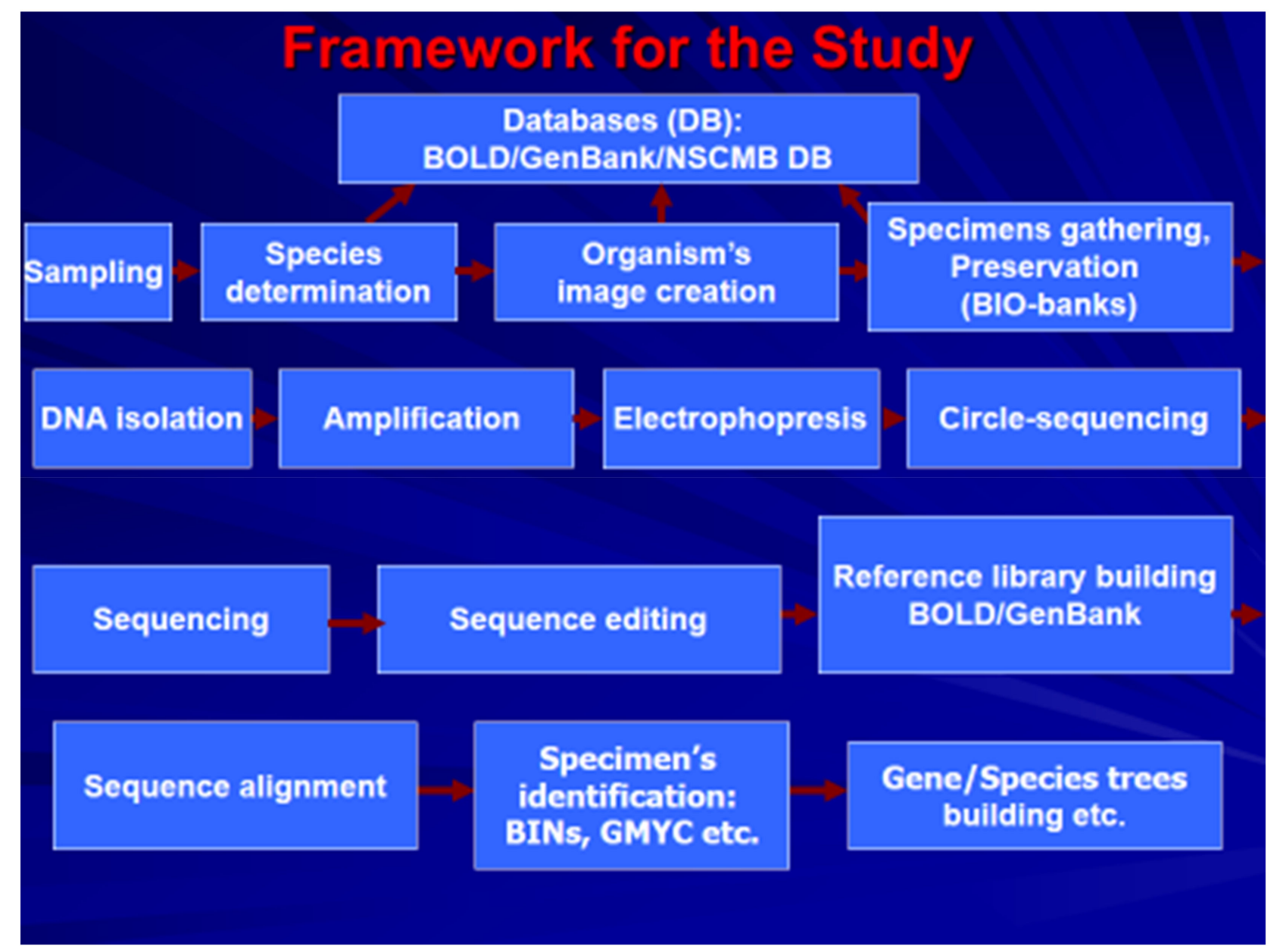

Figure 1. The scheme that illustrates the main steps and activities necessary to develop DNA barcoding and other associated fields of research.

DNA barcoding. MMs are involved in the global program for a description of biological diversity (biodiversity) on the molecular and bioinformatics platforms. For most invertebrates and vertebrates, a nucleotide sequence (hereafter, the sequence) of the Co-1 (COI, cox-1, etc.) gene, which encodes subunit 1 of cytochrome $c$ oxidase of mitochondrial DNA (mtDNA), is used as a standard MM or DNA barcode. For practical needs, the first half of the gene with a length of approximately 650 base pairs (bp) is conventionally used as a barcode. Other MMs or barcodes are more suitable for plants or fungi $[9,10]$.

The basis for successful identification of studied eukaryotic species is the low intraspecific variability (low sequence differences between specimens of the same species) but a much higher interspecific divergence of specimens (between specimens of different species). The average intraspecific divergence is approximately $0.5-1.0 \%$, while the inter- 
species diversity is up to $10 \%$, according to data on animals [11-18] ) that well agrees with pilot findings $[1,2,19]$. However, that matter is complex and there might be vast heterogeneity of distance scores even among the taxa of a single level, e.g., genera of different organisms [11,12,14] (see discussion in Section 3.3).

DNA barcoding has many applied use [20]. Recently, one of such appeared due to the globalization and intensification in international trade of food products. The identification of specimens during export and import operations has achieved great importance. Falsified trademarks of seafood such as fish fillets, caviar, etc., can be accurately identified with this kind of MMs, which help customers and retailers avoid significant economical and reputational losses [21-25]. These late matters require special consideration in an assignment or review.

MMs for identification of stocks, lines, and breeds of animals. At this level, Co-1 and other mtDNA MMs are not quite suitable because of their low variability within a species, as mentioned above (although with some exceptions); MMs of nuclear DNA (nDNA) are usually more conservative in animals and even less applicable at this level. The highest efficiency for the identification of differences between specimens sampled from animal populations, breeds, and lines and for the authentication of single individuals in higher organisms could be obtained by the use of microsatellite DNA loci and single nucleotide substitutions (SNPs). One of MM's applications is the identification of hybrids and invasive species.

3. MMs are of greatest importance in medicine (in particular, in diagnostics of such diseases as breast cancer, prostate cancer, colon cancer, etc.) and forensic medicine in particular (exclusion of specimens from suspects in criminalistics). The scope of MM application includes also the monitoring of genetic safety to assess risks of the use of recombinant DNA and genetically modified organisms (cells) in the food and medical industries [10]. A few other applications of MMs, particularly in fishery/aquaculture, were reviewed separately [24,26].

The approximate framework of DNA barcoding and neighboring areas is explained schematically (Figure 1). From this scheme, the importance of the databases (DB) or scientifically defined libraries of properly curated specimens becomes obvious. As is shown in the following sections, this scope influences both societal needs and basic science. The significance of studies described above, besides the obvious areas such as medicine and biodiversity, are particularly important for the validation of biology paradigms, as well as for the iBOL program itself. On August 7, 2020, the iBOL accumulated results of studies on $11,429,832$ specimens of living organisms. The number of specimens with barcodes in BOLD (barcode of life database; http:/ / boldsystems.org, accessed on 7 August 2020) is 8,466,913; the number of species identified by barcodes is 314,777 (BOLD; Taxonomic Browser). All these data are accompanied by unified documentation that complies iBOL standards and are freely available via the Internet. The contribution of the Russian Federation and RUSBOL (http:/ / www.imb.dvo.ru/misc/barcoding/index.htm, accessed on 7 August 2020) to DNA barcoding research in the BOLD on 7 August 2020 (http:/ /www.boldsystems. org/index.php/Public_BINSearch?query=Russia, accessed on 7 August 2020) constitutes 42,174 published records (=records with sequences), forming 7972 barcode clusters (BINs) represented by 263 institutions (laboratories). The records referred to the iBOL Russia node on the above date refer to 27,320 species names, representing 6099 species. By its activity level, the Russian Federation is in the middle of the list of participant states, along with Brazil and France.

For general usage, it should be mentioned the latest DB Midori, a database that verifies the GenBank (www.ncbi.gov, accessed on 13 May 2021) data and able to eliminate incorrect sequences (http:/ / www.reference-midori.info, accessed on 13 May 2021; [27], etc.).

Biodiversity description based on the DNA barcoding approach is successful for the vast majority of taxa, and this fact, along with the ability to delimit species and identify specimens requires explanation and theoretical justification [15,28-31]. In one of the approaches to understanding the biological basis of this phenomenon, it was proposed to 
focus primarily on the "pairwise distance" metric, which is equivalent to the $p$-distance or fraction of different nucleotides in a pair of randomly sampled sequences [30] and to evaluate the molecular features of $C_{0}-1$ and the whole mtDNA molecule [31].

Quite a different approach is considered in this study: the species/specimens delimiting ability is explained mainly by the prevalence of the geographical model of speciation in nature. This model assumes that organisms can accumulate stochastic mutations and unique nucleotide substitutions in DNA chains due to the formation of daughter populations (taxa) under gene flow break between them. With the implementation of this model, specimens of different species are experimentally identified by DNA barcodes, and a correlation of $p$-distances and taxon ranks can be detected by an appropriate analysis [13-15,17,28,29,32]. In other words, as shown below with some examples, nucleotide substitutions between specimens of different species could be detected directly in a laboratory as cumulative changes in the sampled DNA/gene nucleotide chains of comparable size.

To address these questions, special consideration of empirical data is required. This consideration must be accompanied by a diversified analysis together with a notion on genetic bases of speciation, as well as with the relevant provisions of the biological species concept (BSC) and, more generally, with Neo-Darwinism, or synthetic theory of evolution (STE). The relevance of this study is also caused by the need to consider the criticism of the BSC/STE paradigms based on the concepts of extensive introgression [33-36] and reticular evolution [36,37]. These issues have already been considered in part [13-17,28,29,38,39], but still need a more comprehensive quantitative analysis, which is carried out in the present paper.

This study represents an original overview of data and concepts on genetic introgression, reticulation, and a few of mentioned above issues on general genetics and general biology. A new data set that includes up to 12,572 records in MS Excel format is presented for the quantitative meta-analysis of hybrid evidence, genetic introgression, and some records including reticulation data as well (Table S1, Section 2).

In the review, the analysis of genetic distances, that made before for mostly mtDNA Co- 1 and $C y t-b[13-17,28,29,39]$ is also extended for other MMs like $16 S$ rRNA and complete mitochondrial genomes (mitogenomes) based on publicly available sequences from GenBank. These latter sequences (16S rRNA and mitogenomes) were not used in previous publications on comparative-and-evolutionary analysis of genetic distances along with taxa scaling. The variability of genetic distances in the hierarchy of taxa for the $16 \mathrm{~S}$ rRNA gene was first provided in the dedicated literature in Russia and is also considered along with mitogenomes' data in three specific taxa [40-42]. Here these kinds of distance data are combined for a large set of vertebrate mitogenomes as an original impact (details of the analysis are provided in Section 3).

One of the key objectives of this brief review is to answer the question of whether the available molecular genetic data allow generalizations on the wide presence of genetic introgression between biological species and on the frequent occurrence of reticulation in the studied gene trees, and, if the answer is negative, then, conversely, whether these shreds of evidence are consistent with BSC/STE. STE itself is certainly not a dogma and requires further development. Currently, STE in biology is a general evolutionary concept and, therefore, may be referred to as a theory. However, based on the formal scientific definition, it is unlikely to meet the criteria of a theory. A real theory should include a description in mathematical terms and/or should represent a rigorous model, e.g., a computer model, and have a property to predict events. A consideration of this drawback is available in the relevant literature and some theoretical studies with different levels of generalization appear periodically $[12-15,39,43-51]$.

Data on the possible influence of gene introgression on species evolution, the evolutionary fate of taxa, including reticulations of phylogenetic trees, and the consistency of modern molecular genetic data generally with Neo-Darwinism has been provided in many papers $[33-35,48,52-56]$. 
Concerning the problems of the review, it is important to clarify some phylogenetic terminology in the very beginning. The term "gene tree" was introduced a long time ago [45]. A gene tree is a phylogenetic tree constructed using data for a single gene. This term opposes the concept of the species tree [39] (p. 189), [45,51] (p. 240), which includes a phylogenetic signal for several genes and may incorporate other traits.

A phylogenetic tree, including a gene tree, may have a different topology, including common roots for branches/nodes/clusters (monophyly), or, inversely, have branches with polytomies referred to as para- or polyphyly, indicating reticulation events. Reticulation events or actions are such that cause uncommon descent due to depauperates in Mendelian inheritance, gene or genome duplications, genetic introgression, etc. Some other issues, like sampling errors due to the lack of a signal to resolve a tree topology, are also possible and discussed shortly elsewhere. The topology as well may differ when inferred using different gene (sequences) depending on parameters of lineage diversification.

There are various controversial issues regarding the BSC/STE. This review focuses mainly on four questions: (1) What methods of identification are most appropriate for the detection of hybrids and genetic introgression, or gene flow? (2) What the facts obtained based on markers of mtDNA and nDNA do indicate? (3) Is there any evidence in the literature for the consistency of molecular variability in phyletic lines or taxa with BSC/STE? (4) How often do reticulations and polytomies of gene trees occur, and what is the main information signal revealed by their topology?

The review analyzes primarily data for animal taxa, but many ideas are applicable also to other taxa, including unicellular organisms.

The general statistical analysis was performed on the basis of MS Excel statistical software and STATISTICA 6.0 [57]. ANOVA/MANOVA, DFA, and other ordinary or multidimensional parametric and nonparametric approaches for statistical testing were widely used. Most details of these tests are explained in publications cited in the review.

\section{Estimation of Genetic Introgression: Concept, Terms, and Methods}

\subsection{Notion and Investigation of Hybrids}

The content of the section below, as well as in some other parts of the present paper, has been considered recently in a brief overview [16], in the congress proceeding [29], or as a translation of the Russian experimental paper [42]. Currently, the annotation on the subject is provided in the regular issue in this paper, the available base of evidence is widened and I present a quantitative statistical analysis of data (Supplement, Table S1).

Two concepts are most important for the understanding of the essence of genetic introgression: the notions of hybrid and hybridization. "A hybrid is a genetic mixture, an offspring from a crossing between genetically different organisms". A specimen with a mixed pedigree, a mestizo, can also be considered a hybrid [51] (p. 151). For testing, a heterozygote of a distant cross for one or more loci could be a hybrid indicator. Hybridization is the process by which hybrids have appeared. Meanwhile, the difference between a simple intrapopulation mating and a crossing for different populations, lines, and broodstocks from one hand, and species from the other should be recognized. In common sense, hybrids are considered to be descendants of more distant crosses. In addition to $\mathrm{F}_{1}$, other types of hybrids occur in nature: $\mathrm{F}_{1} \times \mathrm{F}_{1}=\mathrm{F}_{2}, \mathrm{~F}_{1} \times \mathrm{P}_{1}=\mathrm{F}_{\mathrm{b}}$, etc.

Hybridization can be artificial or natural. This review is focused primarily on natural hybridization. As noted above, a sharp distinction should be recognized between hybridization and hybrids (hybrid individuals) that occurred afterward artificially or naturally; it is also underlined that hybrids are defined in terms of genotypes that occurred through mating in the natural environment, between normally outbreeding organisms. Agamic, clonal forms, and artificial cases are not considered in this review.

Hybrid individuals may not be exactly intermediate by phenotype between the parental forms and might be closer to one of the parents; in nature, they usually have a decreased fitness compared to that in the parents. The hybrid index, e.g., $I_{H}$ [53], may be far from 0.5 in this case, and the fitness score may decrease from 1 to a lower level 
accordingly [12,51] (Ch. 10). (During artificial propagation and broodstocks' breeding, quite an opposite effect is possible, i.e., heterosis). However, in natural populations, the excess of variability originated from distant crosses often has no positive effect but provides an additional segregation genetic load $[12,43,58,59]$.

From the strict definitions of gene flow [52], it becomes evident that unambiguous detection of hybrids in nature is possible by using nuclear gene markers, which allows identification of the opposite alleles of two parents in the offspring genotype. mtDNA, which is normally inherited in vertebrate animals maternally, can be used with a certain caution. For this reason, the presence in samples of a fragment of mtDNA (or even a complete mitogenome) of Type A specimen in the study of Type B specimens can be explained by a hybridization event that happened in the past. However, a researcher should also exclude other genetic events such as horizontal transfer, recombination, etc. Hybrids obtained only by mtDNA markers should be considered as preliminary identified, since, as noted above, the hybrid genotype identification is certain by the nuclear genes and availability of both parental alleles.

Evidence for the presence of hybrids may actually reflect the recombination of a region of the mtDNA with nDNA genes. For example, such events were observed in carp fish of the Gila robusta complex [55]. Subsequently, the transfer of mtDNA from Brachymystax lenok to Hucho taimen genome was also described [60]. However, both mentioned examples are only preliminary indices of possible hybridization, because they are entirely based on mtDNA markers. The fact that taxonomically different fishes can interbreed and produce fertile offspring are well known [61]. Researchers [61-65] combined data from more than 4000 studies, including evidence for both artificial and natural hybridization between fish. Some data on this topic were also presented elsewhere [16,29]. In the above papers, among other issues, it was noted that genotypic documentation of hybrids and introgression was not done for a bulk of comparisons.

It is believed that natural hybridization is more common in fish than in other vertebrates. A similar conclusion may be done for marine invertebrates because the sex chromosome determination system is not well developed for these groups. In a majority of vertebrates, sex determination depends on the determinative gene [66] located on the $Y$ chromosome. However, in fish, sex is determined by several factors and only rarely by the sex chromosomes, which may be completely absent [67]. For example, molecular studies on salmon revealed a weak correspondence of the male's and female's phenotypes with sex-specific genetic markers [68].

The increased hybridization level in these taxa can be based on several features of the biology of fish and shellfish: external fertilization, weak behavioral isolating mechanisms, unequal numbers of two potential parental species, competition for limited spawning habitats, and, at last, susceptibility to secondary contact of recently diverged forms [53,69,70]. These features can vary significantly depending on local conditions. Natural and humaninduced impacts on habitats can be the factors that stimulate fish hybridization [53,64]. Industry-induced changes in ecosystems in North America are also considered as inducing hybridization between the initially allopatric and naturally sympatric pairs of species [71-74]. For salmon, such examples were reviewed several times $[64,75,76]$.

Available sources indicate that hybridization occurred roughly in $25 \%$ of plant species and $10 \%$ of animal species [33]. In many papers, it is assumed that hybridization per se creates inevitably as a byproduct of genetic introgression. However, this relationship, if it exists, is not simple, as is shown below. Evident cases of genetic introgression are usually observed among young, recently diverged species. For certainty, it is better to focus on the certain notion of species, a kind that better fits BSC, i.e., the biological species by Mayr's [77] definition, or on similar versions [39] (p. 86), [51] (p. 95), [78]. This choice is important because such species is a reproductively isolated unity and is closest to the population genetic terms considered in this review. Many relevant papers have considered environmental aspects of hybridization [79], impacts of recent historical changes [80], and 
frequency of natural hybrids in a vast number of taxa: e.g., in birds [81] in comparison with other vertebrates $[82,83]$.

There are at least four methods of hybrid identification: morphological, karyological, biochemical genetics, and molecular genetics $[28,29,39,51,53]$. MMs are defined as a protein or allozyme, nDNA and mtDNA gene markers most suitable for detection of hybrids and answering questions on the presence of genetic introgression. Detection of hybrids and introgression by the MM analysis of allozyme and nDNA markers is robust if two parental taxa are fixed for different alleles at two or more loci. For instance, for two loci $C$ and $\mathrm{D}$ with a pair of alleles each, $C_{1}$ vs. $C_{2}$ and $D_{2}$ vs. $D_{3}$, the hybrid individual $\mathrm{FH}\left(C_{1} C_{2}\right.$ $D_{2} D_{3}$ ) could be well-identified. Two parental taxa are homozygous in this case for different alleles at $C$ and $D$ loci, whereas $F_{1}$ hybrids will be heterozygous for these alleles at two diagnostic loci. However, when hybridization proceeds further than the $F_{1}$ stage, hybrid descendants will give a broad mixture of recombinant genotypes, including genotypes that are identical to the two parental genotypes. In such situations, there is an ultimate necessity for estimating gene flow in precise genetic terms (e.g., Nm, m, Fst, etc.). To date, not so many studies have used such exact population genetic approaches, and the available reviews show examples of some uncertainties [36,37,84]. Even a summary of recent findings gave a lot of empty cells for the key variables, such as $\mathrm{Nm}$ and hybrids' frequency or their type (Table S1, Supplement). A brief look at some numerical outcomes from them will be done in the sections below.

Empirical data confirm that separate allozymes and nDNA markers are most effective when the parents have different fixed alleles $[29,39,51,53]$ and/or when multi-genomic data are applied $[85,86]$ with estimates of parameters such as $\mathrm{Nm}$, m, Fst, etc. Complex approaches, e.g., the use of mtDNA and nDNA markers can be even more successful as being able to determine, for example, the direction of a parent's sex in a cross [87]. An integrated approach by MMs and morphometry is also well applicable to assess the genotypic effects, in a particular heterozygote, on the phenotype [88-90]. Examples of successful use of MMs combination were reported for turtles of the genus Mauremys [85], for cichlids of the genus Ophthalmotilapia from Lake Tanganyika [86], for mussels of the Mytilus ex. group edulis complex with GLU-5 and other MMs [39,51,89-98], as well as for many other taxa [87].

To summarize the paragraphs above, it should be stated as follows [29]:

(1) Hybrid's identification and detection of genetic introgression are subjects of a major challenge. First, these require accurate genetic analysis with hybrid identification based on many loci and a comparison of descendants of various types $\left(\mathrm{F}_{1}, \mathrm{~F}_{2}, \mathrm{~F}_{\mathrm{b}}\right.$, etc.). Subsequently, estimates of allele frequencies, gene flow, and a generalization should be obtained based on these components.

(2) In this context, BSC is the basic concept for selective testing groups of organisms in genetic terms; intraspecies groups, as well as inbred lines and agamic species (lines of organisms), cannot be considered as representative for understanding the essence of hybridization events and genetic introgression.

(3) The experimental tools available for analysis in genetics are straightforward and sufficient for hybrid identification and assessment of introgression level.

\subsection{Genetic Introgression across Species Boundaries}

Distinguishing hybrids is often complicated or even impossible if hybridization has been successful and a variety of offspring occurred: $F_{1}, F_{2}, F_{b}$, etc. When backcrosses or next-generation hybrids are common, the occurrence of recombinant genotypes at a quite high frequency is possible. In such cases, it is difficult to discriminate $F_{1}$ hybrid from a rare parental multiple-locus heterozygote, even when completely diagnostic nuclear loci are used [53]. There are specialized software, e.g., structure (http:/ / pritch.bsd.uchicago. edu/structure.html, accessed on 17 November 2019) [99], DNAsp v5 [100], GENEPOP 3.3 [101,102], MIGRATE-N v 3.0.3 [103,104], SIMCOAL [105], etc., to resolve complicated cases including migration. However, the matter itself and numerical simulations of it 
are quite sophisticated, and unambiguous population genetic solutions are sometimes impossible to obtain due to the complexity of hybridization events in nature and, especially, in temporal dynamics. The matter considered is even more obscure because there are no precise tools yet to delimit the taxa that have reached and those that have not reached the species rank. In this condition, exact delimitation of species is a very important challenge to evolutionary genetics and evolutionary biology in general $[13,14,51,106,107]$. The subject is rather complicated, but it is possible to establish an approach that would test a zoological species, which was conventionally identified, with species status for its members identified using MMs, such as the DNA barcode approach with an ID [20] or with a special index, e.g. Barcode Index Number (BIN; BOLD, www.boldsystem.org, accessed on 8 July 2015) or others (see Section 3).

It seems that among the earliest work using MMs to study the occurrence of hybrids in nature were on fish and shellfish, and particularly on mussel. In the 1980s, the frequency of hybridization among nine sunfish species (genus Lepomis) inhabiting two geographic locations in the southeastern USA was assessed using mtDNA markers in combination with allozyme loci [61]. One of the major findings of this research is especially relevant for the current review: no mtDNA or electrophoretic evidence (nDNA base markers) of introgression between the Lepomis species was detected; all the hybrids found appeared to be strictly $F_{1}$. Since then, most studies on hybridization phenomena in nature have reported the presence of mostly $\mathrm{F}_{1}$ offspring, and also hybrids' swarms with gene pools merging due to massive introgression, and other cases [34,87].

More examples of mtDNA analysis are considered separately below. Prior to this consideration, some data collected by the author's team for mussels from the Sea of Japan such as the Pacific mussel, Mytilus trossulus, and an introduced Atlantic-and-Mediterranean species, M. galloprovincialis, are presented. In our first report, combined allozyme-andmorphometric data showed an approximately 5\% hybrid occurrence rate in the Sea of Japan waters in Russia, South Korea, and Japan. Hybrid occurrence varied annually within the limit of $1.6 \pm 0.9 \%$ to $8.9 \pm 1.7 \%$ [88] (hereafter, values are the mean \pm its standard error). The direction of gene flow was determined as $M$. trossulus $\rightarrow$ M. edulis $\rightarrow$ M. galloprovincialis and the species rank of $M$. trossulus was accepted as unambiguous. However, the M. edulis and M. galloprovincialis taxa were considered to be subspecies/semispecies based on the orthodox BSC [88]. The above conclusion well agrees with the age of taxa, as M. trossulus is known to be the most ancient member of the Mytilus ex. group edulis [88,108]. In the recent reports on these mussels, the genetic variability in the northwestern Sea of Japan (NWSJ) is considered [89,98]. Eight populations were analyzed using eight polymorphic enzyme loci and two nDNA markers (GLU-5 and ITS-1,2). Both enzyme and nDNA markers showed a similar pattern of frequency variation in the two parental species and hybrids. The genotypes of the native Pacific mussel, $M$. trossulus, were predominant, while hybrids were generally rare (Figure $2 \mathrm{~A}$ ). The overall abundance of the invasive species, M. galloprovincialis, was relatively low. However, it reached $42 \pm 2 \%$ in one aggregation, in a sample collected from Possjet Bay off the town of Zarubino, where an international ferry line is operated. The greatest number of hybrids have also been found in this aggregation.

When searching for the genetic introgression, and assuming the average generation's length as three years, the $\mathrm{Nm}$ rate per generation was estimated approximately at $\mathrm{Nm}=5$, following Fst rate variation in time. In a different approach, supposing that interspecies gene flow is due to offspring generations such as $\mathrm{F}_{2}, \mathrm{~F}_{3}$, and $\mathrm{F}_{\mathrm{b}}$, rather than from $\mathrm{F}_{1}$, the fraction of interspecies migrants, estimated as $F_{b}+F_{2}$, etc., equals $0.9 \% \pm 0.7 \%$ (Figure $2 B$ ). The obtained evidence suggests a continuous invasion of M. galloprovincialis into NWSJ. Judging by the occurrence of hybrids of all types, it is evident that the rate of genetic introgression between two taxa is low, varying over 14 years in the sampled Vostok Bay area (NWSJ) from 0\% in 2012 and 2013 [89] up to $8.95 \pm 1.68 \%$ in 1999 [96]. 


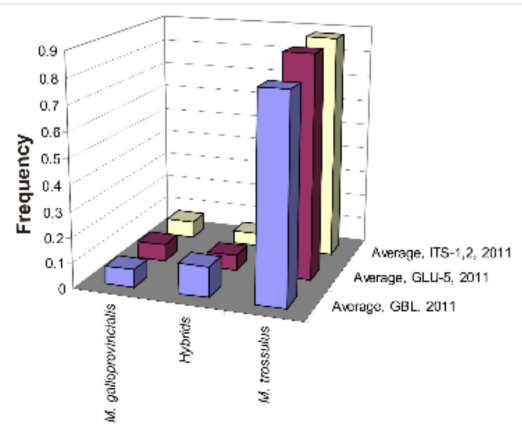

(A)

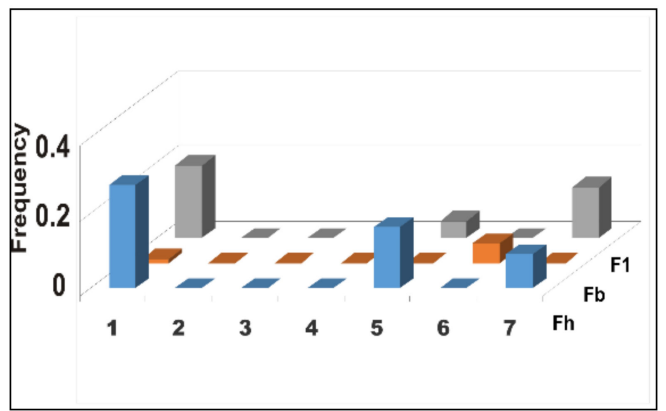

(B)

Figure 2. Two histograms of the frequency distribution of the native species M. trossulus, hybrids, and the invasive species M. galloprovincialis in mussel settlements in the NWSJ (Peter the Great Bay and adjacent waters in the Sea of Japan). The left histogram (A) shows a hybrid genotypic group Fh simulated in the Structure software (8 biochemical-genetic loci, GBL, and two nDNA markers, GLU-5 and ITS-1,2). The Y-axis in both figures is the frequencies of genotypes in the total sample from the studied settlements. The right histogram (B) shows examples of hybrid occurrence with small or no gene introgression, as evidenced by the decreased score levels for $F_{b}$ offspring. The three rows in figure $(\mathbf{B})$ are examples of frequency variation of three types of hybrids $\left(F_{h}, F_{b}, F_{1}\right)$ of the two mussel species. On the $\mathrm{X}$-axis are the numbers of samples from mussel settlements in the NWSJ (Modified from $[89,98]$ ).

A. Interspecies hybrid frequency sampled for the study of hybrids and introgression in animal taxa. Numerical data are from the sheet Tb-Dt-Plot-Hybr that presents data on hybrids availability the same as in Table S1 (Supplement) but without empty cells. Below the $X$-axis, numerals denote the ordinal position of taxa listed in Columns 2, 4, and 5 from the sheet Tb-Dt-Plot-Hybr. The numerals from 1 to 21 denote as follows: 1, European butterflies; 2, Flower butterflies; 3, Drosophila; 4, World birds; 5, Grouse of Britain; 6, British ducks; 7, Birds of paradise; 8, American warblers; 9, World tits; 10, Tits; 11, Warblers of Palaearctic; 12, European mammals; 13, Sea stars; 14, Hard clam; 15, Mussels; 16, Eels; 17, Redfish; 18, Sea turtles; 19, Fur seals; 20, Land snails; 21, Breams (scientific names are in column 5 in the sheet Tb-Dt-Plot-Hybr).

Many theoretical and empirical investigations of hybrid occurrence, hybridization, and genetic introgression, with a variety of other examples available, are summarized elsewhere in the literature [33,37,52,84,109-118]; some other data can be found in recent author's overviews ([28,29,42]; see also the Supplement file, Genet-introgr+reticul-evidenceTable1S-etc.xlsx).

Obviously, many aspects of hybridization are obscure and complex, and, thus, some contradictions are possible and may not be resolved soon. For example, in Vertebrates, birds seem to be most prone to hybridization $(10-19 \%,[81,84,119,120])$, while amphibians and fish hybridize less frequently but, apparently, with a higher rate than reptiles and mammals [37]. Such an impression may arise due to a biased sampling of different taxa because no statistical evaluation has been made. Unfortunately, no convincing summary statistics are available in cited papers and to the author's knowledge elsewhere. In the current paper, I tried to fill this gap (Figure 3; see also Supplement, Figures S2 and S3). Particularly, the entire data set includes reanalysis of former reviews' data and new sources that combine up to 12,572 specimens of animals (Supplement, Table S1, Figure S1 spreadsheets).

From these data, it is evident that scores of supposed genetic exchanges available as hybrid frequency $\left(F_{h}\right.$, mostly for $\left.F_{1}\right)$ and $N m$ vary widely. In the $F_{h}$ rate, the range is from 0 to $100 \%$; in the $\mathrm{Nm}$ rate or similar statistics, the range is from 0.4 to 3 (except the score of 36.6 for Tanganyikan Cichlids, as these species hardly fit BSC); the averages of these two variables are as follows: $\mathrm{F}_{\mathrm{h}}=25.7 \pm 5.8 \%$ and $\mathrm{Nm}=5.7 \pm 4.7$ (Figure 3A,B; Supplement Table S1, and Figure S3A, Figure S3B in sheets Tb-Dt-Plot-Hybr and Tb-Dt-Plot-Nm). Some scores, as noted in comments to Table S1 (sheet Table S1, last column). Many uncertainties, 
especially for hybrids' frequency, may arise because represent crosses of an unknown rank, e.g., they may represent intraspecies categories or morphospecies (morphotypes).

A

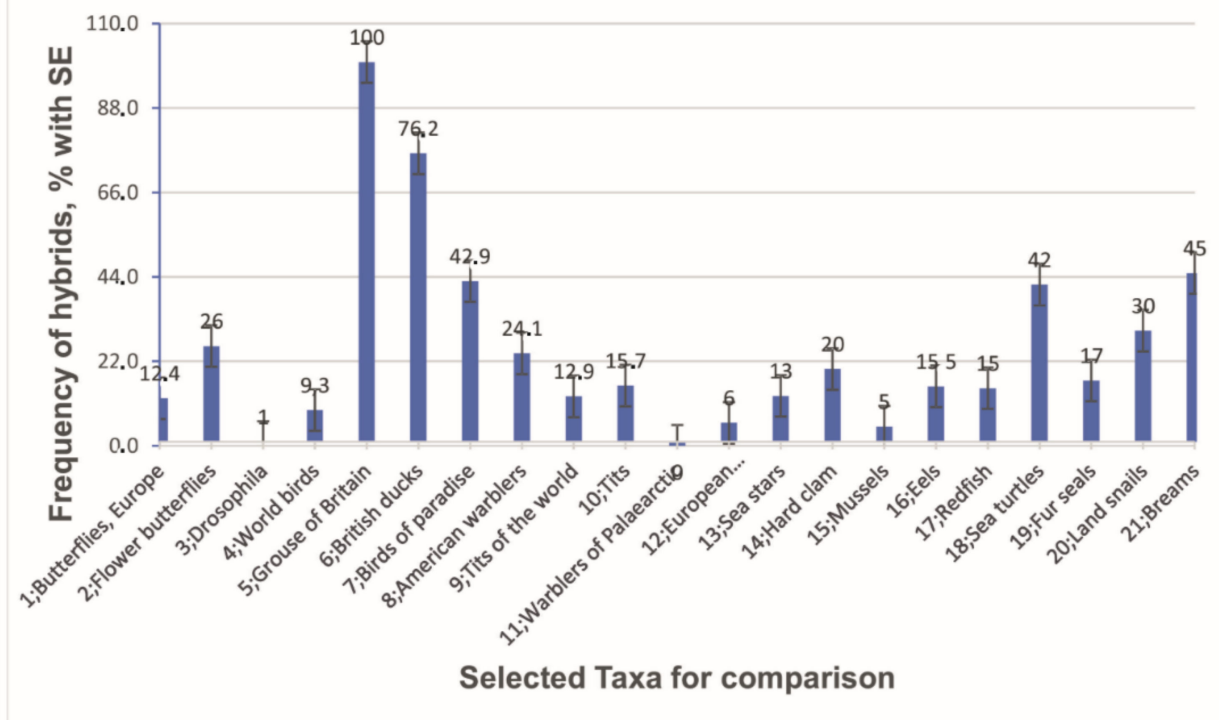

B

Interspecies exchange rate $\mathrm{Nm}^{*}$

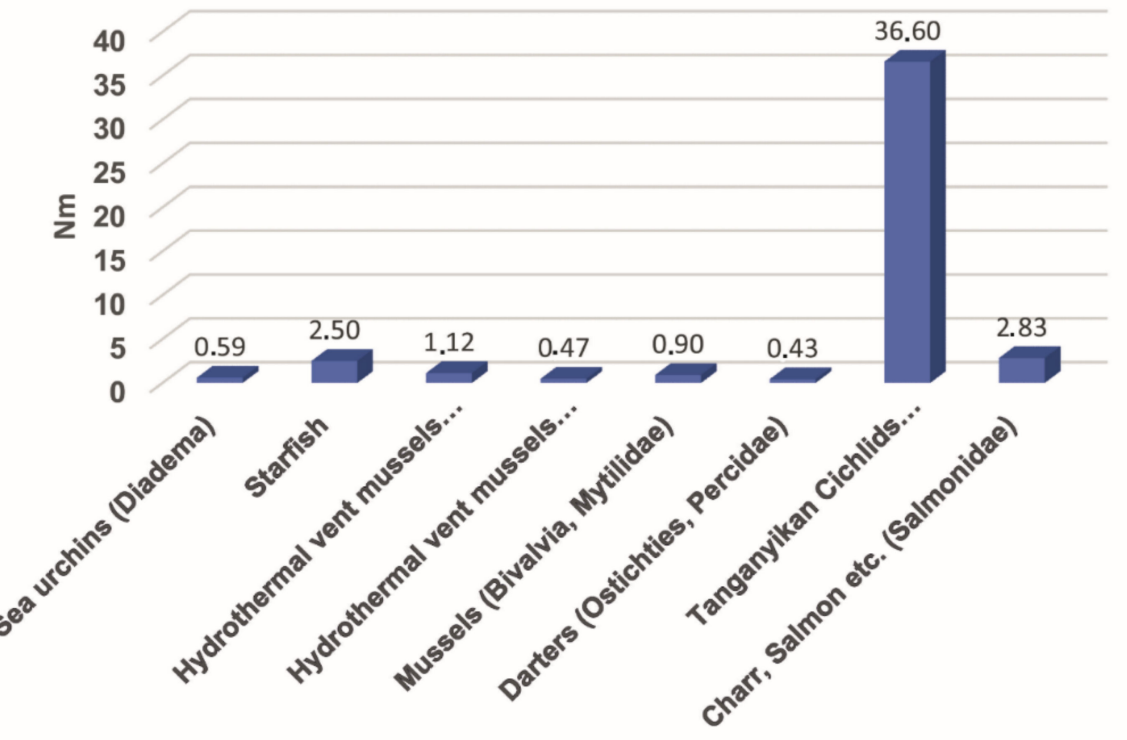

Figure 3. Summary of studies on hybrids and introgression in animal taxa.

The analysis presented here shows that roughly $2 / 3$ cases identified as genetic introgression are, in fact, $\mathrm{F}_{1}$ hybrid occurrence and many are evidence for mtDNA spread across species border but for the nuclear genome an admixture did not notice at the sufficient extent (mtDNA data are commented in the summary Table S1; Supplement: sheet Table S1, last column). After examination of the summary table in mentioned overview by Arnold and Fogarty [36], it became evident that the actual number of cases of genetic introgression is exaggerated, as follows from the discussion in the current paper. 
Let us consider another case, where there is an increase of $F_{h}$ with sample size, and try to discriminate $F_{h}$ presence and the actual genetic introgression in the cases, where the evidence is more or less sufficient (i.e., $F_{h}$ scores are genetically confirmed and fit the conditions for qualitative analysis). A special regression analysis was carried out which provided the conclusion that differs from common expectation: i.e., the greater the species specimens' number (SSN), the more frequent are hybrids. The relationship that actually obtained is different: SSN negatively related to the hybrid numbers. The variation row for regression analysis has $n=16$, unfortunately small, due to a large number of empty cells in the original database (Supplement, Table S1 sheet); also, the second variable (SSN) deviates from normality. Despite these weaknesses, it is evident from the score of the Spearman correlation coefficient, which is an appropriate measure for this case, that there is a negative and significant relationship between two variables, $F_{h}$ and SSN: $r_{S}=-0.7354$, $p<0.001, n=16$. Two bivariate plots with the normal and exponential curves are provided to visualize the relationship (see Supplement, sheet Figure S2. Fh vs SSN; Figure S2A,B). As evident from data in the sheet Figure S2, the Fh vs. SSN correlation is also negative for the Pearson correlation score but is non-significant. Thus, further investigation into this issue is needed. Anyway, obtained data may contradict some of the above-cited views as regards the widespread genetic introgression between species in nature.

According to recent comparative genomics data, the genetic introgression, when thoroughly documented, show examples of mosaic pattern for different parts of the genome (including mitogenome); therefore, it is obvious that many loci remain nearly unchanged even with the certain cases of introgression $[86,121,122]$. The cases of unidirectional gene exchange $[86,123]$ and the interspecific cytoplasmic gene (mtDNA) flow in the absence of nuclear gene flow that proved long ago are obviously underestimated [124,125]. As already mentioned, Arnold [33] estimated the rate of hybridization among animals as $10 \%$. Taking into account the above presented data, the actual percentage of genetically introgressed animal species might be even smaller, around $5.7 \%$, as illustrated above (with $95 \%$ confidence interval from -3.7 to 10.4). Therefore, in support of the goal (1) of the current review, the conclusion is possible that, in spite of consistency or inconsistency to BSC, species as entities in nature are mostly able to maintain their integrity and authenticity, at least in a testable retrospective or provisional perspective. Data presented in Section 3 below should reinforce this idea based on another kind of evidence.

\section{The Topology Mode of Gene Trees, Molecular Diversity between Taxa, and Fit of These Data to the BSC/STE and DNA Barcoding Practice}

\subsection{Topology of Gene Trees Inferred from Empirical Data}

A number of different modes for building single-gene trees are available, but most have a bifurcative topology (i.e., fork-like splitting of branches in the nodes) with monophyletic or, sometimes, paraphyletic (polyphyletic) branches. Numerical estimations of congruence between the different gene trees do not easy to carry out because their patterns can be different and not comparable. However, phylograms with known branch lengths can be compared, and, when estimated, their congruence is determined as varying and, in many cases, phylogenies match quite well $[40,41,126,127]$. The bad fit of topologies determined by different genes are also found, but such a pattern usually resulted from the technical-andinformational complications for proper reconstruction. For instance, some discrepancies can occur due to the lack of information capacity of sequences used (small length; e.g., as found for $16 S$ rRNA in flatfish; [128]) when the number of OTU (operation taxonomic units) being high, as well as due to an inappropriate choice of MM (gene) for the tree reconstruction (too conservative or too variable), and due to other drawbacks in the work with trees [129].

In regards to lineage sorting, which objectively can cause different topologies for different genes, a tree built on the whole mitogenome may be more informative then, that on a single gene, as was shown by the results obtained for 100 fish taxa [130], as well as for flatfishes (Pleuronectiformes; [131]) or cyprinid fishes (Cypriniformes, Cyprinidae) [40,132] with the complement of 13 protein genes of the mitogenome. In addition, similar outcomes 
are reported for many other fish taxa whose representative samples of nDNA genes were used in the analysis [133-138]. An approach with numerical simulations and building time-trees for a vast set of candidates' nDNA loci among Eukaryotes, sampled from 2274 studies representing 50,632 species/specimens of the global time-tree of life, has revealed that genetic diversity basically increases with the rank of taxa [127].

There are four main outcomes from the discussed results and from the typical topological signal in gene trees [28,29]: (i) most trees have the evident branch(es) for outgroup; (ii) within taxa of the order rank, major branches/nodes/clusters are represented by families/subfamilies; (iii) lower in the hierarchy, there are well-supported branches that represent different genera of families; and (iv) there are sets of the most close branches comprised of specimens/individuals which are clustered as single-species representatives. A certain fraction of trees contains obscure intragenic and intrafamily clusters that represent usually cases of unresolved topology in some nodes, paraphyly or polyphyly within taxa, with needs for explanation and further examination (usually, later data lead to revisions of taxa in systematics). Let us see how to manage the above data in Section 3.1.

The latter issue is not easy to resolve. For example, currently, there is no general approach to estimate the number of false neighbors in a cluster from gene trees sampled from studies that are available in the literature. Therefore, no common approach exists to find the degree of reticulation within the trees. Attempts to find a general solution for biodiversity quantification are still made. They are based on several techniques, e.g., on DNA barcoding framework [28-30,139], although each of these studies is aimed at different outcomes. Other approaches, such as using Poisson tree processes (PTP) [140], a method similar to the PTP, with generalized mixed yule coalescent (GMYC) theory [141], a comparison of bifurcating patterns in sequence-based species trees [142], and GMYC with the ideology of K/ $\theta$-approach [126], were suggested as well.

A bulk of complications may arise during tree analyses, like those for flatfish Co-1 and $C y t-b$ gene trees that exhibited paraphyletic intragenic clusters for Hippoglossoides and Pseudopleuronectes [131] (Figures 1 and 2). However, in the example above, this fact simply reflects morphological misidentifications of some specimens; sometimes, they merely exemplify synonymy of Latin names for a single species, as has been discussed elsewhere [131,143]. The misclassifications mentioned here highlight a problem that is well known in systematics $[28,29,139,144]$ and which usually leads to numerous taxonomic revisions. There is another apparent problem that occurs because of the obscure discrimination of a taxonomic misidentification and the actual false branching in molecular phylogeny, which is caused by genetic reticulation. Beyond the taxa of someone's expertise, it is usually impossible to resolve that issue even with thorough documentation of such cases. Some other complications are evident, e.g., an mtDNA- vs. nDNA-based tree's discordance [145], a difference in the rate of substitutions for different genes, a lineage sorting related to Ne variation, and many others created during the genome era in phylogenetics $[45,54,146,147]$.

\subsection{Congruence between DNA Barcode Data and Conventional Taxonomy Classification}

A simple approach was suggested for empirically resolving a topology signal that is based on molecular evidence and classic taxonomy data [28,29]. For this, a concordance is tested between the molecular classifications by DNA barcode data specified as BIN scores and the specimens that zoologically determined by taxonomy experts and gathered in BOLD $[28,29]$. The BIN score in BOLD is currently defined mostly for Co- 1 sequence data among specified OTUs. BINs are independent of previous taxonomic identifications. Thus, BINs provide means for confirming the match between barcode sequence clusters and species/specimens' designations by a conventional taxonomy.

In the papers cited above [28,29], data were sampled from three fish barcoding projects, TZFPC [148], FERU [149], and SCFAA [150]; species identification and DNA barcoding are based on the expertise of the projects' authors. These data were selected as close to the authors' expertise in these fish taxa to minimize complications in interpreting data. Based on BIN scores, it was found that $81.4 \pm 2.3 \%$ of specimens for species, $84.0 \pm 3.9 \%$ 
of specimens for genera, and $88.0 \pm 5.8 \%$ of specimens for families of these BOLD projects were concordant with the zoological determinations for these fish taxa (Figure $4 \mathrm{~A})$. Thus, up to the family level, such molecular marker as Co-1 that comprises a partial sequence of approximately $600 \mathrm{bp}$ well suits to specimen identifications. In the analysis, no statistically significant differences were observed between the three levels (Figure 4A). More details of the analysis are provided in the cited reports and supplementary data [28]. In the research presented, the LOG-transformed total numbers of BIN scores (LOG-BIN ALL variable, Y-axis that explains specimens' variation determined by morphology) and the concordant classifications among OTU-clusters for BIN scores (LOG-BIN concordant variable, $\mathrm{X}$ axis) were comparable for the three project's data (see Figure 4A). In addition, a linear regression and positive correlation for combined data of our own research and other research teams, FERU/TZFPC and SCFAA, was shown [28,29]; see Figure 4B,C). The coefficient of determination $\left(\mathrm{R}^{2}\right)$ for the linear regression function estimated for the two used data arrays is equal to $90 \%\left(r_{p}=0.989, p<0.001\right.$, for the least effect). Thus, based on data in Figure 4, a conclusion can be drawn that at the above-considered level (iv) all the sequences/individuals of the same species are determined as single-species clusters, while at level (iii) members of different species are classified into separate genera by their morphology, according to the common practice, with quite high precision. The same is true for the family level (ii), comprised of specimens of different genera. Two kinds of branches at levels (iii) and (iv) sharply differ on any scale of genetic distance [12,13] and, therefore, useful as a tool for DNA barcoding by iBOL and related projects.

Before proceeding to the following analysis below, where data on the distances calculated directly from sequences or retrieved from trees are used, let us have a look again at the phylogenetic information at the family level (ii), which is valuable for understanding the above-presented correlations on distance vs. topology. An important point for a molecular phylogenetic investigation is family monophyly.

It is especially valuable for the large one, for instance for such large flatfish families as Pleuronectidae, Soleidae, and Bothidae, for which basic information is currently zoological (e.g., FishBase, etc.); however, relevant data on flounders have also been obtained from molecular phylogenetics [133,134,151]. Monophyly of at least three family-level lineages has been suggested within the Pleuronectoidei, initially based on the results for $12 S$ and $16 S$ rDNA [133] and then for $16 S$ rDNA among several families [134]. Later, a similar paper appeared for Co-1, Cyt-b, as well as for the mitogenome data on, mostly, Pleuronectidae [131]. A phylogeny resolving relationship within the Pleuronectidae family is still under development, and recently a wide approach based on several mtDNA and nDNA sequences have been applied [138].

Some complications have also been reported: for example, paraphyly in the subfamily Pleuronectinae and paraphyly in the genus Limanda, found recently based on larval morphology and molecular markers [131,152]. However, in spite of the data on interspecies hybridization in some flatfish taxa [153], paraphyly even in this fish taxon generally seems attributable rather to the problem of weakness of traits under the morphological determination of individuals (and a habitat change impact in the latter case) than to the origin of the vast hybrid flock in the area of this study in the Baltic. However, such events cannot be ruled out, as it follows, for instance, from discussion in Section 2.2 and data for mussels $[97,154]$.

Another large fish lineage, Cypriniformes, has been subjected to even vaster research, including biochemical genetic and molecular phylogenetic approaches [32,40,132,135,136,155-161]. For these taxa, in spite of numerous occurrences of hybrids, the existence of polyploid forms, and examples of speciation through interspecies hybridization $[158,162]$, most branches obtained in gene trees and mitogenome-based trees indicate that there is no prevalence of genetic reticulation among fishes of the order Cypriniformes. Trees' nodes there also exhibit mostly a bifurcative type, as is observed in flatfish. In this very diverse taxon, there are certainly problems with molecular systematics that inevitably occur for any big gene tree as compared to small ones. For instance, for the Leuciscinae, big trees have a lower 
congruence as shown quantitatively by using the Dendroscope software [40]. However, such sort of data is most probably indicating a necessity to increase an information signal from sequences for achieving a better topology resolution for large taxa.

A

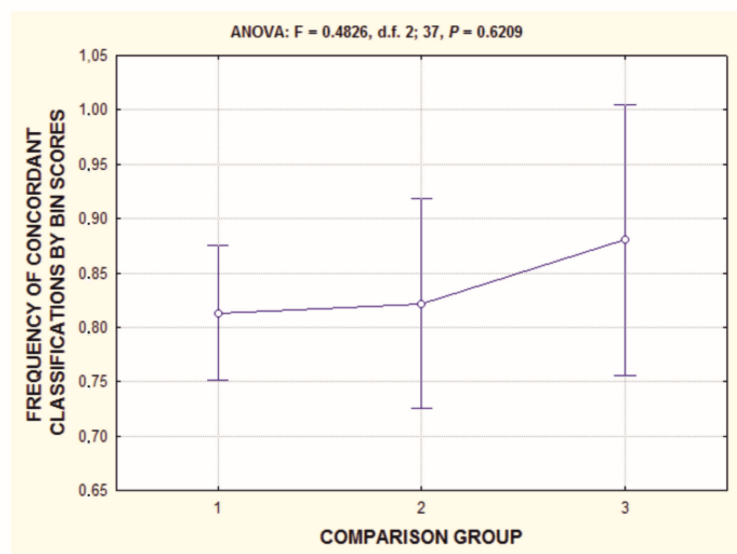

B

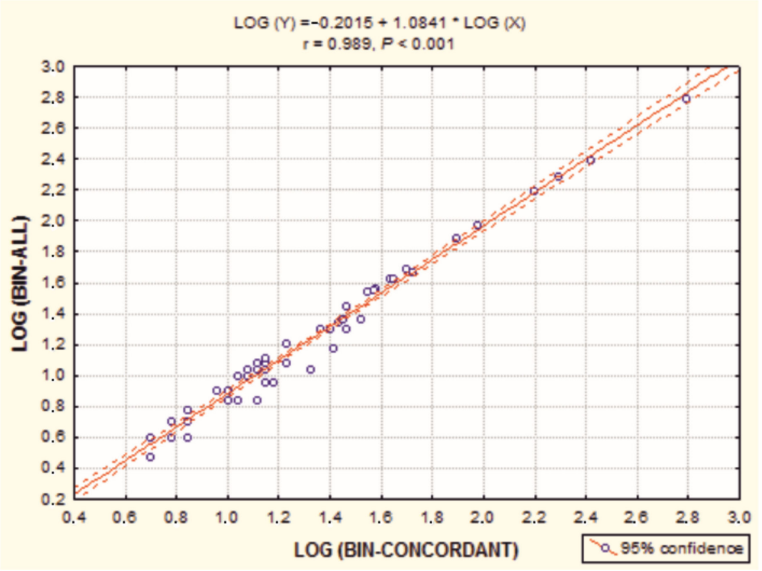

C

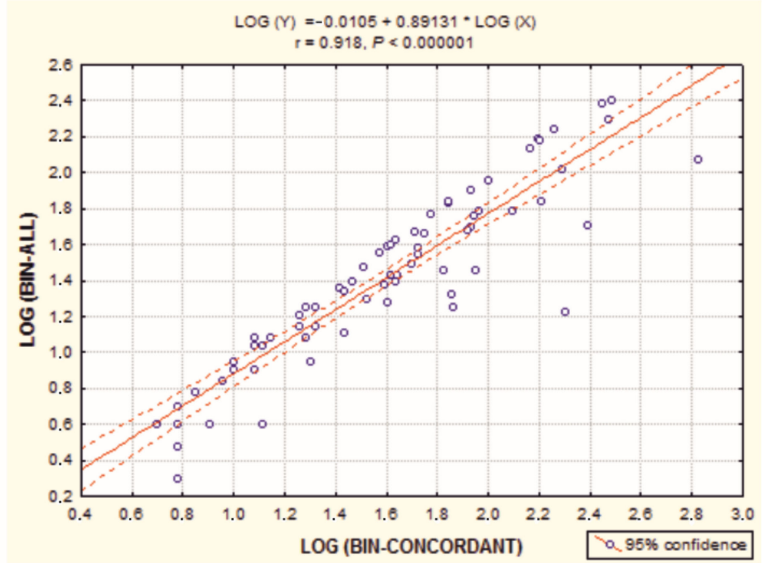

Figure 4. (A) ANOVA of BIN score distribution in three fish taxa analyses that were retrieved from BOLD. BIN, barcode index number showing the frequency of concordant classifications ( $\%, Y$-axis) of a tested species-specimen by Co- 1 mtDNA barcode records and its correspondence to the entire set of records in the BOLD data base that was named in an independent way. The comparison groups $(X-$ axis) are specimens assigned to the certain species (1), genus (2), or family (3). Frequencies of concordant classifications do not differ among the analyzed research projects (see for details [28]); the same also applies to the three comparison groups in the plot (top). The overall average of concordant classifications by BIN estimates is over $82 \%$. $(B, C)$ Regression analysis of covariation of two variables in the BOLD projects of fish. LOG (BIN-ALL) values (a variable that designates zoologically identified specimens for intraspecies, intragenic, and intrafamily categories as recorded in BOLD, $\mathrm{Y}$-axis) plotted against LOG (BIN-CONCRDANT) scores (all concordant OTU-clusters for Co-1 mtDNA barcode records or sequence-specimens for the same three categories, $\mathrm{X}$-axis). Variations show a statistically significant positive linear dependence of the two variables for combined projects FERU/TZFPC (B) and SCFAA project (C). The overall covariation of the two variables for the data set, as estimated by the coefficient of determination on BIN scores, is $R^{2}=98 \%$ and $R^{2}=84 \%$, respectively, for two analyses. More details of the analysis are provided elsewhere [28,29].

Beyond the above-mentioned data, there are opposite evidence in support of many genetic reticulations in trees. Such signal comes from trees built for taxa of hybrid zones, as recently found for Mytilus ex. group edulis (e.g., [154,163-166], etc.). In addition, complexes of rich tropical/near-tropical fauna give other examples of reticulations [86,167]. There are 17 records of phylogenetic discordance that are summarized in the mentioned review on the introgression impact [36] (Table 1). Being very important, these facts do not alter the general signal on bifurcations and monophyly prevalence in gene trees for a bulk of animal lineages or the ability of MM to delimit fish taxa with a precision of over $80 \%[28,29,149,167]$ 
and other taxa, as clearly evident from the iBOL library. The DNA barcoding evidence relies on the vast empirical BOLD information that validates these conclusions for shallow phylogenies up to the genus level for a vast majority of known eukaryotic taxa and, surprisingly, extends even up to the family level.

Along with the goals of the review and due to the relevance of population genetics concepts, the BSC is accepted as a framework for key considerations in this paper, despite its applicability to mainly bisexual organisms $[47,78,168]$. However, for the vast diversity in nature, several other species concepts have also been established, and they are cited here just to provide readers with a list of their authors [47,77,169-175]. The second important clarification is a keystone to the STE, as summarized by Bush [44], who extended the known Dobzhansky's [176] concept, the idea on the gene flow break as a crucial factor for the speciation process. Even a further generalization is possible on this issue: "If one could prove that speciation is possible without a gene flow break under a wide genetic exchange, with no gene flow break between lineages, then the BSC/STE must certainly be rejected" $[28,29,39,51]$. Similarly, it can be stated as follows: if the prevailing speciation modes can create new species without long-term gene pool isolation between parental populations and without reproductive isolation barriers (RIBs), then the BSC/STE paradigms would be disproved? [28,29,39,51]. For the BSC/STE and evolutionary genetics theory, a direct relationship between genetic distance (D) and time (T) is also naturally derived, as clearly defined, for instance, for protein loci due to the accumulation of neutral mutations over time since isolation [45] and in the general case for MMs as a time-dependent coalescent process in lineages [146].

From this position, the natural general assumption can be made that MM clusters, including Co-1 barcode, represent species/specimens and must exhibit covariation with ranked taxa that obviously differ in their age from the lowest to the highest. A more focused empirical-and-theoretical consideration of the latter issue is available elsewhere [13,14,28,29,39,51,127]. Certainly, there should be exceptions to the general case where species are single interbreeding populations; such cases include phylogeographic divisions present within species [54] that can have their own complicated evolutionary fate $[121,147,177]$ and those with shared, or overlapping barcode clusters due to a complicated history of species formation and mtDNA introgression ([30] (Figures 2 and 3); see also discussion in Section 2), or even a more complex scenario with introgression-reticulation and genome mosaicism [121]. Actual exceptions from the general assumption that may arise due to the lack of divergence or its small value to be detected by current MM techniques are also expected [178]. For example, if a species originates by the geographic mode (D1) with long-term accumulation of substitutions in isolation, then all the above-explained expectations come true, but when the event of speciation depends on the action of regulatory alterations, chromosomal changes, etc. (speciation modes D3, T2-T4; [46]), then most sampled MMs specimens may become indistinguishable and nearly all DNA barcoding markers will fail.

\subsection{Molecular Diversity in Taxa of Different Ranks}

Data representing variation in genetic distances within species and between taxa of different ranks have confirmed that for most organisms, or, more specifically for animals, there is a positive relationship (close to liner for single genes) between two variables: distance score in a comparison group (taxon) and taxa rank [12-15,39]. This trend is similar for the entire mitogenome (Figure 5; [30]), as well as for the temporal relationships of Linnaean ranks of eukaryotes, showing hierarchical mode for time score and taxa ranks (Figure 5; [127]). Barcode clustering (BIN concordance) and morphology-based taxa ranks (ALL-values concordance) linear relationship (see Figure 4) also should be caused by gradual processes of evolutionary divergence. There are evident exceptions from this rule, showing that gaps between species clusters can be minimal or nearly absent at all $[30,40,149]$. As a rule, such cases refer to the taxa that have not yet achieved the biological species rank (subspecies, semispecies, or young species), but could also occur due 
to the presence of species (forms), which are not biological species but, as defined above, originated via genetic transformations, that has not caused (or slightly did) the structural genes per se to be involved routinely in the MMs analysis [12-14,28,29,39]. In addition, there are examples of drastic differences in genetic distances among taxa of the same rank for different lineages, like amphibians, birds, and mammals [12-15,39,54,179]. For this reason, the general DNA barcoding approach and the single scale of genetic distances for the entire biota could not be a universal tool, which fact seems to be overlooked in some summarizing analyses on this topic [30]. There is a way to resolve this complication. In brief, the idea is to use an algorithmic approach based on equations of the set theory after preliminary experimental testing of species/specimens distinctness by means of multiple descriptors of genetic diversity and divergence (with a defined number of estimates of variability and divergence, both for structural and regulatory genes) along with the use of some phenotypic identifiers. Further, it is suggested to carry out special experimental testing of some specimens (individuals) from complicated situations, which can help exclude the cases of conflict: e.g., species vs. modifications [12-15,39,51].

(A) Variation in the mean values of $p$-distances among four comparison groups for flatfish: (1) $p$-distances inside the species, between individuals of the same species; (2) $p$ distances within the genus, between individuals of different species of the same genus; (3) $p$-distances within the family, between species of different genera of the same family; (4) $p$-distances within the order, between the species of different families of the same order. Color rectangles below main curves in the plots, A and B, show supposed low or absent distance increase along with taxa ranks in a case of no D1 prevalence (after [42] with a modification).

(B) Plot of variation in the arithmetic mean values of $p$-distances among three comparison groups for cyprinids: (1) intraspecies, among individuals of the same species; (2) intragenic, among morphologically distinct species of the same genus; (3) intrasubfamily, among genera of the same subfamily. The effects, i.e., the differences among the mean $p$-distance scores in comparison groups, are exemplified at the top of plots. Bars show a 95\% confidence level. Both ANOVA statistical analyses substantiate the intergroup differences (after [40] with a modification).

(C) Temporal relationships of divergence along with Linnaean ranks in Eukaryotes. Taxa grouping is shown on top. The X-axis on the bottom is time-scale. Dots with $95 \%$ confidence intervals showing divergence mode among taxa. Vast sample of nDNA markers prove the hierarchical-and-positive dependence of genetic distance and taxa rank (After Hedges et al., 2015 [127]).

In conclusion, let us have a general look at data on genetic distances for different ranks of taxa. A set of such data have been presented elsewhere for two genes, Co- 1 and $C y t-b[12-15,51]$ (Chapter 7)); here, new data for complete mitogenome and its 13 protein loci are summarized in Figure 5 [40,42]. All these data allow three main conclusions:

Conclusion 1. Species delimitation at $C o-1, C y t-b$ and other certain mtDNA gene sequences is highly efficient and unambiguous because of the low intraspecies and high interspecies diversity for these markers [28,29,39,51]. For mitogenome, this statement is valid as well (see Figure 5; A and B, Groups 1 vs. 2).

Conclusion 2. The positive-and-proportional relationships between distance score and taxonomic rank (Figure 5; $[13,14,28,29,39,51,127])$ support the idea that speciation in most cases follows the geographic mode (D1 Type, see details in [13,14,39,51] (Chapter 7)) and that phyletic evolution prevails at least in animals. Thus, molecular data empirically prove, on a new level, the basics of the BSC/STE and neo-Darwinian paradigms and their interpretation of speciation and evolution. 
A

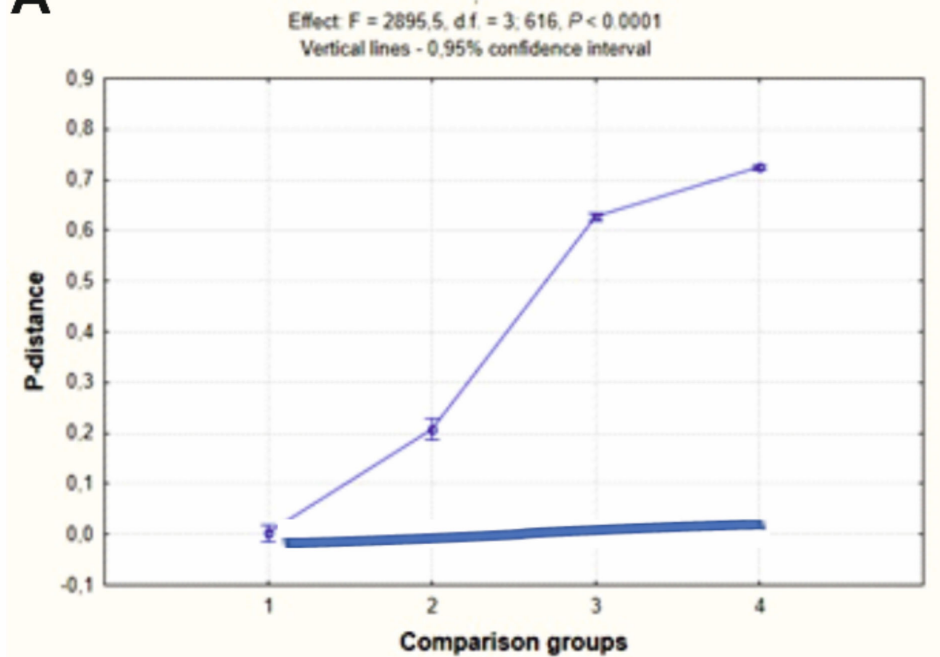

B

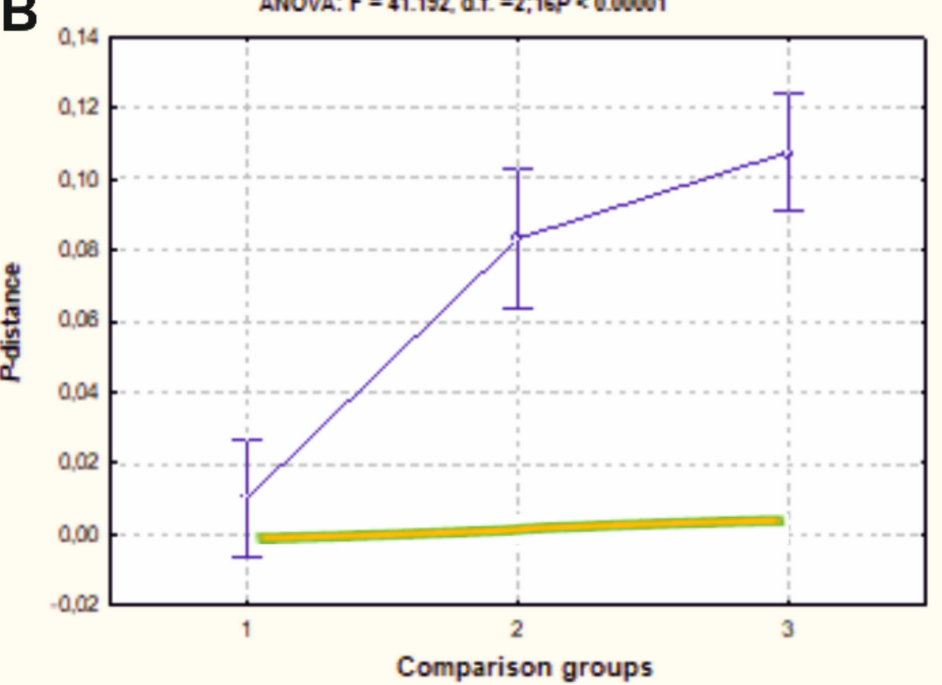

C

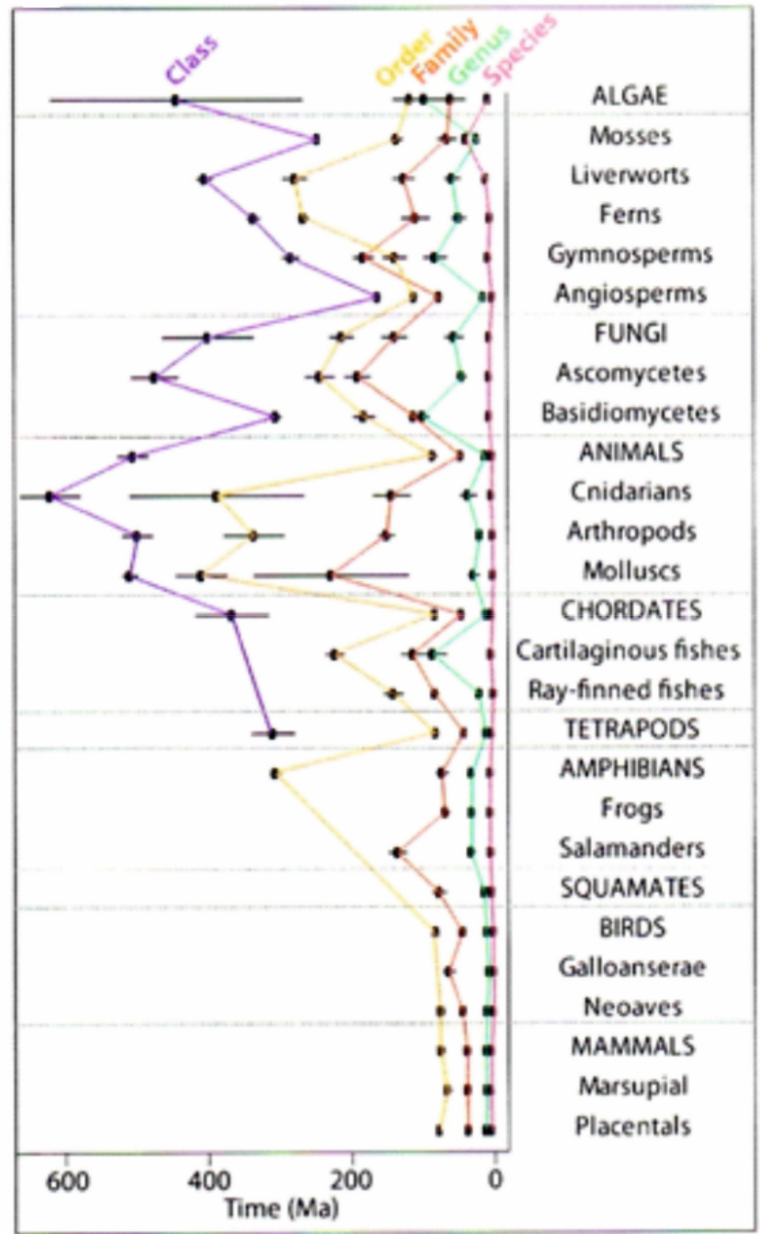

Figure 5. $P$-distance distribution in animal taxa for complete mitogenome in flatfish (A), 13 protein gene sequence data of mtDNA in minnow (B), and time-dependent variation for nDNA markers in a sample of 50,455 species/specimens of different taxa of Eukaryotes (C).

Conclusion 3. As it follows from the obtained and presented data in the discussion, the alternative modes of speciation (D3, T2-T4, etc.) are rare in nature. In the case of alternative hypotheses, i.e., if other speciation modes are equally represented in nature, the relationship between distance and taxa rank should be weakly expressed with small or absent slope (flat); probability of other speciation modes prevalence is certainly disproved by the analysis and other evidence presented in this review (see Figure 5; color rectangles below main curves in the Plots A and B show supposed low or absent distance increase in a case of no D1 prevalence). Such a conclusion does not necessarily mean that other modes are absent or less important. This means rather the well-known fact: Darwinian evolution may prevail with time and provide the current biodiversity of living forms. However, drastic genetic transformations can sometimes produce principal novelties (aramorphosis), although these are rare events in evolution. The latter statement, however, currently have no sufficient empirical or theoretical basement and, therefore, is subjected to debates, which have been continued for many years and has both proponents and opponents.

Many important issues remained out the consideration because of the limited space of the paper, like the heteroplasmy and mitochondrial pseudogenes presence. Recently serious concerns rose on the heteroplasmy widespread occurrence in many taxa of Eukary- 
ote $[180,181]$ which ignorance may seriously cause conclusions in evolutionary genetics, phylogenetics, and molecular genetics. The impact of pseudogenes' presence in a genome may be also underestimated [182] and needs a special investigation.

Supplementary Materials: The following are available online at https:/ / www.mdpi.com/article/10 $.3390 /$ ani11051473/s1.

Funding: This research received no external funding.

Institutional Review Board Statement: All applicable international, national and institutional ethics statements when using published research data have been followed. Only published and a metaanalysis data (Supplement) are used in the paper.

Informed Consent Statement: Not applicable.

Data Availability Statement: Not applicable.

Acknowledgments: The author gratefully acknowledges financial support from the Russian Science Foundation (grant \#14-50-00034) related with the section on molecular phylogenetics and tree reticulation. Funding was also received in part as a grant from the Government of the Russian Federation in the framework of the Federal Project \#13.1902.21.0012 "Basic Problems in the Research and Conservation of Deep-Water Ecosystems ... " by the Ministry of Science and Higher Education of the Russian Federation (agreement \#075-15-2020-796). No other financial, consulting, or personal relationships have influenced this work and no writing assistance was obtained. My thanks are due to E.P. Shevtsov for his proofreading a draft of the manuscript.

Conflicts of Interest: The author declare that the research was conducted in the absence of any commercial or financial relationships that could be construed as a potential conflict of interest.

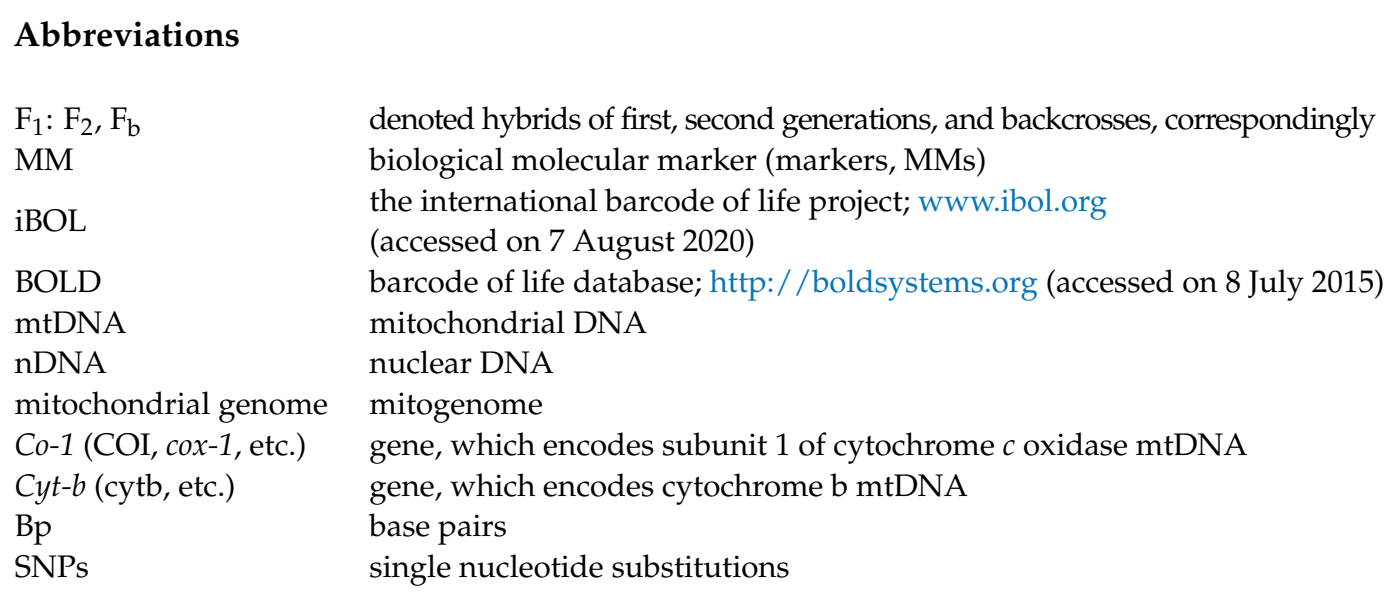

\section{References}

1. Hebert, P.D.N.; Cywinska, A.; Ball, S.L.; Dewaard, J.R. Biological identifications through DNA barcodes. Proc. R Soc. B Biol. Sci. 2003, 270, 313-321. [CrossRef] [PubMed]

2. Hebert, P.D.N.; Ratnasingham, S.; De Waard, J.R. Barcoding animal life: Cytochrome c oxidase subunit 1 divergences among closely related species. Proc. R. Soc. B Biol. Sci. 2003, 270, S96-S99. [CrossRef] [PubMed]

3. Antonov, A.S.; Belozzerskii, A.N. Comparative analysis of nucleotide composition of deoxyribonucleic acids of some vertebrates and invertebrates. Dokl. Akad. Nauk SSSR 1961, 138, 1216-1220.

4. Antonov, A.S.; Miroshnichenko, G.P.; Slyusarenko, A.G. The data on DNA primary structure in the plant systematics. Usp. Sovrem. Biol. 1971, 74, 247-261.

5. Zuckerkandl, E.; Pauling, L. Molecules as documents of evolutionary history. J. Theor. Biol. 1965, 8, 357-366. [CrossRef]

6. Hubby, J.L.; Throckmorton, D.H. Protein differences of Drosophila. II. Comparative species genetics and evolutionary problems. Genetics 1965, 52, 203-215. [CrossRef]

7. Altukhov, Y.P. Populyatsionnaya Genetika Ryb (Fish. Population Genetics); Pishchevaya Promyshlennost: Moscow, Russia, 1974.

8. Nanney, D.L. Genes and Phenes in Tetrahymena. Bioscience 1982, 32, 783-788. [CrossRef]

9. Shneyer, V.S.; Rodionov, A.V. Plant DNA Barcodes. Biol. Bull. Rev. 2019, 9, 295-300. [CrossRef] 
10. Zhokhova, E.V.; Rodionov, A.V.; Povydysh, M.N.; Goncharov, M.Y.; Protasova, Y.A.; Yakovlev, G.P. Use of DNA barcoding and DNA fingerprinting for analysis of the quality of medicinal plant materials and medicinal herbal preparations. Biol. Bull. Rev. 2019, 9, 301-314. [CrossRef]

11. Kartavtsev, Y.P.; Lee, J.-S. Analysis of nucleotide diversity at genes Cyt-b and Co-1 on population, species, and genera levels. Russ. J. Genet. 2006, 42, 341-362, (In Russian, Translated in English) [CrossRef]

12. Kartavtsev, Y.P. Analysis of sequence diversity at mitochondrial genes on different taxonomic levels. Applicability of DNA based distance data in genetics of speciation and phylogenetics. In Genetic Diversity; Mahoney, C.L., Springer, D.A., Eds.; Nova Science Publishers Inc.: New York, NY, USA, 2009; pp. 17-50; ISBN 9781607413042.

13. Kartavtsev, Y.P. Sequence divergence at mitochondrial genes in animals: Applicability of DNA data in genetics of speciation and molecular phylogenetics. Mar. Genom. 2011, 49, 71-81. [CrossRef] [PubMed]

14. Kartavtsev, Y.P. Sequence divergence at Co-1 and Cyt-b mtDNA on different taxonomic levels and genetics of speciation in animals. Mitochondrial DNA 2011, 2, 55-65. [CrossRef] [PubMed]

15. Kartavtsev, Y.P. Sequence Diversity at Cyt-b and Co-1 mtDNA Genes in Animal Taxa Proved Neo-Darwinism. J. Phylogenet. Evol. Biol. 2013, 1, 1-5. [CrossRef]

16. Kartavtsev, Y.P. Some current concerns of NeoDarvinism: Gene introgression throughout a species border. J. Phylogenet. Evol. Biol. 2013, 1, 1-4. [CrossRef]

17. Kartavtsev, Y.P. Genetic divergence of species and other taxa. Geographical speciation and the genetic paradigm of NeoDarwinism in action. Usp. Sovrem. Biol. 2013, 5, 419-451.

18. Ward, R.D.; Costa, F.O.; Holmes, B.H.; Steinke, D. DNA barcoding of shared fish species from the North Atlantic and Australasia: Minimal divergence for most taxa, but Zeus faber and Lepidopus caudatus each probably constitute two species. Aquat. Biol. 2008, 3, 71-78. [CrossRef]

19. Ward, R.D.; Zemlak, T.S.; Innes, B.H.; Last, P.R.; Hebert, P.D.N. DNA barcoding Australia's fish species. Philos. Trans. R. Soc. Lond. B Biol. Sci. 2005, 360, 1847-1857. [CrossRef]

20. Ratnasingham, S.; Hebert, P.D.N. BOLD: The Barcode of Life Data System. Mol. Ecol. Notes 2007, 7, 355-364. [CrossRef]

21. Miller, D.D.; Mariani, S. Smoke, mirrors, and mislabeled cod: Poor transparency in the European seafood industry. Front. Ecol. Environ. 2010, 8, 517-521. [CrossRef]

22. Hanner, R.; Becker, S.; Ivanova, N.V.; Steinke, D. FISH-BOL and seafood identification: Geographically dispersed case studies reveal systemic market substitution across Canada. Mitochondrial DNA 2011, 22, 106-122. [CrossRef]

23. Muñoz-Colmenero, M.; Blanco, O.; Arias, V.; Martinez, J.L.; Garcia-Vazquez, E. DNA authentication of fish products reveals mislabeling associated with seafood processing. Fisheries 2016, 41, 128-138. [CrossRef]

24. Naaum, A.M.; Hanner, R. Community engagement in seafood identification using DNA barcoding reveals market substitution in Canadian seafood. DNA Barcodes 2015, 3, 74-79. [CrossRef]

25. Nedunoori, A.; Turanov, S.V.; Kartavtsev, Y.P. Fish product mislabeling identified in the Russian far east using DNA barcoding. Gene Rep. 2017, 8, 144-149. [CrossRef]

26. Chauhan, T.; Kumar, R. Molecular markers and their applications in fisheries and aquaculture. Adv. Biosci. A Biotechnol. 2010, 1, 281-291. [CrossRef]

27. Leray, M.; Ho, S.L.; Lin, I.J.; Machida, R.J. MIDORI server: A webserver for taxonomic assignment of unknown metazoan mitochondrial-encoded sequences using a curated database. Bioinformatics 2018, 34, 3753-3754. [CrossRef]

28. Kartavtsev, Y.P. Barcode index number, taxonomic rank and modes of speciation: Examples from fish. Mitochondrial DNA Part A 2018, 29, 535-542. [CrossRef]

29. Kartavtsev, Y.P. Sequence divergence provide a fit between molecular evolution, Neo-Darwinism and DNA barcoding. In Proceedings of the HydromediT 2018, 3rd International Congress on Applied Ichthyology \& Aquatic Environment, Volos, Greece, 8-11 November 2018; pp. 463-479.

30. Kartavtsev, Y.P.; Turanov, S.V.; Zolotova, A.O. Molecular markers and their usage in the biodiversity studies as exemplified on fish. In Studies of Marine Organisms in the Far East: Biodiversity, Monitoring, and Rational Management of Resources; Malakhov, V.V., Chernyshov, A.V., Eds.; Far Eastern Univ. Publisher: Vladivostok, Russia, 2020; Chapter 4; pp. 151-239; ISBN 978-5-7444-4757-1.

31. Stoeckle, M.Y.; Thaler, D.S. Why should mitochondria define species? BioRxiv 2018, 33, 1-30. [CrossRef]

32. Kartavtsev, Y.P.; Sviridov, V.V.; Sasaki, T.; Hanzawa, N. Genetic divergence of far eastern dace belonging to the genus Tribolodon (Pisces, Cyprinidae) and closely related taxa: Some insights in taxonomy and speciation. Rus. J. Genet. 2002, 38, $1518-1531$. [CrossRef]

33. Arnold, M.L. Evolution through Genetic Exchange; Oxford Univ. Press: New York, NY, USA, 1997; ISBN 0199229031.

34. Arnold, M.L. Evolution through Genetic Exchange; Oxford Univ. Press: New York, NY, USA, 2009; ISBN 0-19-857006-6.

35. Arnold, M.L.; Emms, S.K. Paradigm lost: Natural hybridization and evolutionary innovation. In Endless Forms: Species and Speciation; Howard, D.J., Berlocher, S.H., Eds.; Oxford Univ. Press: New York, NY, USA, 1998; pp. 379-389.

36. Arnold, M.L.; Fogarty, N.D. Reticulate evolution and marine organisms: The final frontier? Int. J. Mol. Sci. 2009, 10, 3836-3860. [CrossRef] [PubMed]

37. Borkin, L.J.; Litvinchuk, S.N. Animal hybridization, speciation and systematics. Proc. Zool. Inst. 2013 , 317 (Suppl. S2), 83-139.

38. Kartavtsev, Y.P. Molecular Evolution and Population Genetics, Vladivostok: Dal'nevost, 1st ed.; Gos. Univ. (Far Eastern State Univ. Publ.): Vladivostok, Russia, 2005; p. 234, (In Russian); ISBN 5-7444-1680-3. 
39. Kartavtsev, Y.P. Molecular Evolution and Population Genetics, Vladivostok: Dal'nevost, 2nd ed.; Gos. Univ. (Far Eastern State Univ. Publ.): Vladivostok, Russia, 2009; p. 280, (In Russian; Content, Chapter Abstracts, and Headings are in English); ISBN 978-7444-2271-2.

40. Kartavtsev, Y.P.; Batishcheva, N.M.; Bogutskaya., N.G.; Katugina., A.O.; Hanzawa., N. Molecular Systematics Research, DNA Barcoding of Altai Osmans, Oreoleuciscus (Pisces, Cyprinidae, Leuciscinae), and Nearest Relatives, Inferred from Sequences of Cytochrome b (Cyt-b), Cytochrome Oxidase c (Co-1), and Complete Mitochondrial Genome. Mitochondrial DNA 2017, 28, 502-517. [CrossRef] [PubMed]

41. Turanov, S.V.; Kartavtsev, Y.P.; Lee, Y.-H.; Jeong, D. Molecular phylogenetic reconstruction and taxonomic investigation of eelpouts (Cottoidei: Zoarcales) based on Co-1 and Cyt-b mitochondrial genes. Mitochondrial DNA Part A 2016. [CrossRef] [PubMed]

42. Kartavtsev, Y.P.; Redin, A.D. Estimates of Genetic Introgression, Gene Tree Reticulation, Taxon Divergence, and Sustainability of DNA Barcoding Based on Genetic Molecular Markers. Biol. Bull. Rev. 2019, 9, 275-294. [CrossRef]

43. Lewontin, R.C. The Genetic Basis of Evolutionary Change. Columbia University Press: New York, NY, USA, 1974; p. 13; ISBN 9780231083188.

44. Bush, G.L. Modes of animal speciation. Ann. Rev. Ecol. Syst. 1975, 6, 339-364. [CrossRef]

45. Nei, M. Molecular Evolutionary Genetics; Columbia Univ. Press: New York, NY, USA, 1987; p. 512. [CrossRef]

46. Templeton, A.R. Mechanisms of speciation-Population genetic approach. Ann. Rev. Ecol. Syst. 1981, 12, 23-48. [CrossRef]

47. Templeton, A.R. Species and speciation: Geography, population structure, ecology, and gene trees. In Endless Forms: Species and Speciation; Howard, S.H., Belocher, D.J., Eds.; Oxford University Press on Demand: Oxford, UK, 1998; pp. 32-43; ISBN 0195109007.

48. Avise, J.C.; Wollenberg, K. Phylogenetics and Origin of Species. Proc. Natl. Acad. Sci. USA 1997, 94, 7748-7755. [CrossRef]

49. Kondrashov, A.S.; Yampolsky, L.Y.; Shabalina, S.A. On the sympatric origin of species by means of natural selection. In Endless Forms: Species and Speciation; Howarth, D.J., Berlocher, S.H., Eds.; Oxford Univ. Press: Oxford, UK, 1998; pp. $90-98$.

50. Zhuravlev, Y.N.; Avetisov, V.A. The definition of life in the context of its origin. Biogeosciences 2006, 281-291. Available online: www.biogeosciences.net/3/281/2006/ (accessed on 19 May 2021).

51. Kartavtsev, Y.P. Molecular Evolution and Population Genetics. In A Course for Marine Biology Students; Johnson, M.S., Ed.; CRS Press, Taylor \& Francis Publ. Group: New York, NY, USA, 2015; p. 349; ISBN 978-1-4987-0160-0.

52. Barton, N.H.; Hewitt, G.M. Analysis of hybrid zones. Ann. Rev. Ecol. Syst. 1985, 16, 113-148. [CrossRef]

53. Campton, D.E. Natural hybridization and introgression in fishes. Method of detection and genetic interpretation. In Population Genetics \& Fishery Management; Ryman, N., Utter, F., Eds.; Washington Sea Grant Publications: London, UK, 1987; pp. 161-192.

54. Avise, J.C. Phylogeography. The History and Formation of Species; Harvard University Press: Cambridge, MA, USA, $2000 ;$ p. 447. ISBN 0-674-66638-0.

55. Gerber, A.S.; Tibbets, C.A.; Dowling, T.E. The role of introgressive hybridization in the evolution of the Gila robusta complex (Teleostei, Cyprinidae). Evolution 2001, 55, 2028-2039. [CrossRef]

56. Avise, J. Phylogeography-Retrospect and prospect. J. Biogeogr. 2009, 36, 3-15. [CrossRef]

57. STATISTICA (Data Analysis Software System). Version 6, StatSoft. 2001. Available online: http:/ / www.statsoft.com (accessed on 8 January 2017).

58. Morton, N.E.; Crow, J.F.; Muller, H.J. An Estimate of the Mutational Damage in Man from Data on Consanguineous Marriages. Proc. Natl. Acad. Sci. USA 1956, 42, 855-863. [CrossRef]

59. Altukhov, Y.P. Genetic Processes in Populations, 2nd ed.; Nauka Publ.: Moscow, Russia, 1989.

60. Balakirev, E.S.; Romanov, N.S.; Mikheev, P.B.; Ayala, F.J. Mitochondrial DNA variation and introgression in Siberian taimen Hucho taimen. PLoS ONE 2013, 8, e71147. [CrossRef] [PubMed]

61. Hubbs, C.L. Hybridization between fish species in nature. Syst. Zool. 1955, 4, 1-20. [CrossRef]

62. Schwartz, F.J. World literature on to fish hybrids, with an analysis by family, species and hybrid. Publ. Gulf Coast Res. Lab. Amuseum 1972, 3, 1-328.

63. Schwartz, F.J. World Literature on to Fish Hybrids, with an Analysis by Family, Species and Hybrid: Supplement 1; NOAA Techn. Report NMFS SSRF-750; U.S. Dep. Commerce: Washington, DC, USA, 1981; p. 507.

64. Altukhov, Y.P.; Salmenkova, E.A.; Omeltchenko, V.T. Salmonid Fishes: Population Biology, Genetics and Management; Blackwell Science: Oxford, UK, 2000; p. 354.

65. Barley, D.M.; Rana, B.K.; Immink, A.J. The use of inter-specific hybrids in aquaculture and fisheries. Rev. Fish. Biol. Fish. 2001, 10, 325-337. [CrossRef]

66. Devlin, R.H.; Nagahama, Y. Sex determination and sex differentiation in fish: An overview of genetic, physiological, and environmental influences. Aquaculture 2002, 208, 191-364. [CrossRef]

67. Kirpichnikov, V.S. Genetic Basis for Fish Breeding; Science Publ.: Leningrad, Russia, 1979; p. 392. [CrossRef]

68. Podlesnykh, A.V.; Brykov, V.A.; Kukhlevsky, A.D. Unstable linkage of molecular markers with sex determination gene in pacific salmon (Oncorhynchus spp.). J. Hered. 2017, 108, 328-333. [CrossRef]

69. Avise, J.; Saunders, N.C. Hybridization and introgression among species of sunfish (Lepomis): Analysis by mitochondrial DNA and allozyme markers. Genetics 1984, 108, 237-250. [CrossRef]

70. Avise, J.C. Cytonuclear genetic signatures of hybridization phenomena: Rationale utility and empirical examples from fishes and other aquatic animals. Rev. Fish. Biol. Fish. 2001, 10, 253-263. [CrossRef] 
71. Hubbs, C.; Kuehne, R.A.; Ball, J.C. The fishes of upper Guadelupe River, Texas. Tex. J. Sci. 1953, 5, $216-244$.

72. Nelson, J.S. Hybridization between two cyprinid fishes, Hybopes plumbea and Rhinichthys cataractae, in Alberta. Can. J. Zool. 1966, 44, 663-968. [CrossRef]

73. Nelson, J.S. Occurrence of hybrids between longnose sucker (Catastomus catastomus) and white sucker (C. commersoni) in upper Canananaskis Resorvoir, Alberta. J. Fish. Res. Board. Can. 1973, 30, 557-560. [CrossRef]

74. Stevenson, M.M.; Buchanon, T.M. An analysis of hybridization between the cyprinodont fishes, Cyprinodon variegates and C. elegans. Copeia 1973, 682-692. [CrossRef]

75. Simon, R.C.; Noble, R.E. Hybridization in Oncorhynchus (Salmonidae). I. Viability and inheritance in artificial crosses of chum and pink salmon. Trans. Amer. Fish. Soc. 1968, 97, 109-118. [CrossRef]

76. Altukhov, Y.P.; Salmenkova, E.A. The genetic structure of salmon populations. Aquaculture 1991, 98, 11-40. [CrossRef]

77. Mayr, E. Process of speciation in animals. In Mechanisms of Speciation; Barigozzi, C., Ed.; Alan, R. Liss, Inc.: New York, NY, USA, 1982; pp. 1-20.

78. Timofeev-Resovsky, A.; Vorontsov, N.N.; Yablokov, A.V. A Short Essay on the Theory of Evolution; Nauka Publ.: Moscow, Russia, 1977; p. 301.

79. Genovart, M. Natural hybridization and conservation. Biodivers. Conserv. 2008, 18, 1435-1439. [CrossRef]

80. Seehausen, O. Hybridization and adaptive radiation. Trends Ecol. Evol. 2004, 19, 198-207. [CrossRef]

81. Grant, P.R.; Grant, R.B. Hybridization of bird species. Science 1992, 256, 193-197. [CrossRef]

82. Prager, E.M.; Wilson, A.C. Slow evolutionary loss of the potential for interspecific hybridization in birds: A manifestation of slow regulatory evolution. Proc. Natl. Acad. Sci. USA 1975, 72, 200-204. [CrossRef]

83. Fitzpatrick, B.M. Rates of evolution of hybrid unviability in birds and mammals. Evolution 2004, 58, 1865-1870. [CrossRef]

84. Mallet, J. Hybridization as an invasion of the genome. Trends Ecol. Evol. 2005, 20, 229-237. [CrossRef]

85. Fong, J.J.; Chen, T.-H. DNA evidence for the hybridization of wild turtles in Taiwan: Possible genetic pollution from trade animals. Conserv. Genet. 2010, 11, 2061-2066. [CrossRef]

86. Nevado, B.; Fazalova, V.; Backeljau, T.; Hanssens, M.; Verheyen, E. Repeated unidirectional introgression of nuclear and mitochondrial DNA between four congeneric Tanganyikan cichlids. Mol. Biol. Evol. 2011, 28, 2253-2267. [CrossRef]

87. Nishikawa, T.; Oohara, I.; Saitoh, K.; Shigenobu, Y.; Hasegawa, N.; Kanamori, M.; Baba, K.; Turon, X.; Bishop, J.D. Molecular and morphological discrimination between an invasive ascidian, Ascidiella aspersa, and its congener A. scabra (Urochordata: Ascidiacea). Zool. Sci. 2014, 31, 180-185. [CrossRef]

88. Kartavtsev, Y.P.; Chichvarkhin, A.Y.; Kijima, A.; Hanzawa, N.; Park, I. Allozyme and morphometric analysis of two common mussel species of the genus Mytilus (Mollusca, Mytilidae) in Korean, Japanese and Russian waters. Korean J. Genet. 2005, 27, 289-306.

89. Kartavtsev, Y.P.; Masalkova, N.A.; Katolikova, M.V. Genetic-and-morphometric variability in the settlements of two mussel species (Mytilus ex. gr. edulis), M. trossulus and M. galloprovincialis, in North-West Japan Sea. J. Shellfish. Res. 2018, 37, 1-17. [CrossRef]

90. Katolikova, M.; Khaitov, V.; Väinölä, R.; Gantsevich, M.; Strelkov, P. Genetic, Ecological and Morphological Distinctness of the Blue Mussels Mytilus trossulus Gould and M. edulis L. in the White Sea. PLoS ONE 2016, 11, e0152963. [CrossRef]

91. Heath, D.A.; Rawson, P.D.; Hilbish, T.J. PCR-based nuclear markers identify alien blue mussel (Mytilus spp.) genotypes on the west coast of Canada. Can. J. Fish. Aquat. Sci. 1995, 52, 2621-2627. [CrossRef]

92. Inoue, K.; Takeuchi, Y.; Miki, D.; Odo, S. Mussel adhesive plaque protein gene is a novel member of epidermal growth factor like gene family. J. Biol. Chem. 1995, 270, 6698-6701. [CrossRef]

93. Rawson, P.D.; Hilbish, T.J. Evolutionary relationships among the male and female mitochondrial DNA lineages in the Mytilus edulis species complex. Mol. Biol. Evol. 1995, 12, 893-901. [CrossRef]

94. Rawson, P.D.; Secor, C.L.; Hilbish, T.J. The effects of natural hybridization on the regulation of doubly uniparental mtDNA inheritance in blue mussels (Mytilus spp.). Genetics 1996, 144, 241-248. [PubMed]

95. Rawson, P.D.; Argawal, V.; Hilbish, T.J. Hybridization between the blue mussels Mytilus galloprovincialis and M. trossulus along the pacific coast of North America: Evidence for limited introgression. Marine Biol. 1999, 134, 201-211. [CrossRef]

96. Skurikhina, L.A.; Kartavtsev, Y.F.; Chichvarkhin, A.Y.; Pan'kova, M.V. Study of two species of mussels, Mytilus trossulus and Mytilus galloprovincialis (Bivalvia, Mytilidae), and their hybrids in Peter the Great Bay of the Sea of Japan with the use of PCR markers. Russ. J. Genet. 2001, 37, 1448-1451. [CrossRef]

97. Väinölä, R.; Strelkov, P. Mytilus trossulus in Northern Europe. Mar. Biol. 2011, 158, 817-833. [CrossRef] [PubMed]

98. Kartavtsev, Y.P.; Katolikova, M.V.; Sharina, S.N.; Chichvarkhina, O.V.; Masalkova, N.A. A population genetic study of the hybrid zone of Mytilus trossulus Gould, 1850 and an introduced species, M. galloprovincialis Lamarck, 1819, (Bivalvia: Mytilidae) in peter the great bay in the Sea of Japan. Russ. J. Mar. Biol. 2014, 40, 208-216. [CrossRef]

99. Structure. Available online: http:/ / pritch.bsd.uchicago.edu/structure.html (accessed on 14 July 2015).

100. Librado, P.; Rozas, J. DnaSP v5: A software for comprehensive analysis of DNA polymorphism data. Bioinformatics 2009, 25, 1451-1452. [CrossRef] [PubMed]

101. Raymond, M.; Rousset, F. GENEPOP (version 1.2): Population genetics software for exact tests and ecumenicism. J. Hered. 1995, 86, 248-249. [CrossRef]

102. Rousset, F. Genepop'007: A complete reimplementation of the Genepop software for Windows and Linux. Mol. Ecol. Resour. 2008, 8, 103-106. [CrossRef] 
103. Beerli, P.; Felsenstein, J. Maximum-likelihood estimation of migration rates and effective population numbers in two populations using a coalescent approach. Genetics 1999, 152, 763-773. [CrossRef]

104. Beerli, P. Comparison of Bayesian and maximum likelihood inference of population genetic parameters. Bioinformatics 2006, 22, 341-345. [CrossRef]

105. Excoffier, L.; Novembre, J.; Schneider, S. SIMCOAL: A general coalescent program for the simulation of molecular data in interconnected populations with arbitrary demography. J. Hered. 2000, 91, 506-509. [CrossRef] [PubMed]

106. Brower, A.V.Z. Delimitation of phylogenetic species with DNA sequences: A critique of Davis and Nixon's population aggregation analysis. Syst. Biol. 1999, 48, 199-213. [CrossRef] [PubMed]

107. Sites, J.W.; Marshall, J.C. Operational criteria for delimiting species. Annu. Rev. Ecol. Evol. Syst. 2004, 35, 199-227. [CrossRef]

108. Kafanov, A.I. Subfamily Mytilinae Rafinisque, 1815 (Bivalvia, Mytilidae) in Cainozoe of North Pacific. In Fauna and Distribution of Mollusks: North Pacific and Polar Basin; Far East Center Publisher: Vladivostok, Russia, 1987; pp. 65-103. (In Russian)

109. Yonekawa, H.; Moriwaki, K.; Gotoh, O.; Hayashi, J.I.; Watanabe, J.; Miyashita, N.; Petras, M.L.; Tagashira, Y. Evolutionary relationships among five subspecies of Mus musculus based on restriction enzyme cleavage patterns of mitochondrial DNA. Genetics 1981, 98, 801-816. [CrossRef]

110. Yonekawa, H.; Tsuda, K.; Tsuchiya, K.; Suzuki, H.; Yakimenko, L. Genetic diversity, geographic distribution and evolutionary relationships of Mus musculus subspecies based on polymorphism of mitochondrial DNA. In Problems of Evolution; Kryukov, A.P., Yakimenko, L.V., Eds.; Dalnauka: Vladivostok, Russia, 2000; pp. 90-108.

111. Ferris, S.D.; Sage, R.D.; Huang, C.M.; Nielsen, J.T.; Ritte, U.; Wilson, A.C. Flow of mitochondrial DNA across a species boundary. Proc. Natl. Acad. Sci. USA 1983, 80, 2290-2294. [CrossRef]

112. Smith, G.R. Introgression in Fishes: Significance for Paleontology, Cladistics, and Evolutionary Rates. Syst. Biol. 1992, 41, 41-57. [CrossRef]

113. Suzuki, H.; Yasuda, S.P.; Sakaizumi, M.; Wakana, S.; Motokawa, M.; Tsuchiya, K. Differential geographic patterns of mitochondrial DNA variation in two sympatric species of Japanese wood mice. Genes Genet. Syst. 2004, 79, 165-176. [CrossRef]

114. Suzuki, H.; Filippucci, M.G.; Chelomina, G.N.; Sato, J.J.; Serizawa, K.; Nevo, E. A biogeographic view of Apodemus in Asia and Europe inferred from nuclear and mitochondrial gene sequences. Bioch. Genet.s 2008, 46, 329-346. [CrossRef]

115. Oleinik, A.G.; Skurikhina, L.A. Mitochondrial DNA diversity and relationships of endemic charrs of the genus Salvelinus from lake Kronotskoye (Kamchatka Penisula). Hydrobiologia 2010, 650, 145-159. [CrossRef]

116. Hewitt, G.M. Quaternary phylogeography: The roots of hybrid zones. Genetica 2011, 139, 617-638. [CrossRef]

117. Oleinik, A.G. Molecular evolution of char of Salvelinus genus: Phylogenetic and phylogeographic aspects. In Abstract of Dissertation of Doctor of Biological Science Degree; Zhirmunsky, A.V., Ed.; Institute of Marine Biology: Vladivostok, Russia, 2013 ; p. 47.

118. Saarman, N.P.; Pogson, G.H. Introgression between invasive and native blue mussels (genus Mytilus) in the central California hybrid zone. Mol. Ecol. 2015, 24, 4723-4738. [CrossRef] [PubMed]

119. Panov, E.N. Hybridization and Ethological Isolation; Nauka Publ.: Moscow, Russia, 1989; p. 510.

120. Aliabadian, M.; Nijman, V. Avian hybrids: Incidence and geographic distribution of hybridization in birds. Contrib. Zool. 2007, 76, 59-61. [CrossRef]

121. Edwards, S.V.; Potter, S.; Schmitt, C.J.; Bragg, J.G.; Moritz, C. Reticulation, divergence, and the phylogeography-phylogenetics continuum. In The Light of Evolution, Vol. X: Comparative Phylogeography; Part II; Avise, J.C., Ayala, F.J., Eds.; The National Academies Press: Washington, DC, USA, 2017; Chapter 9; pp. 171-189; ISBN 13 978-0-309-44422-4. [CrossRef]

122. Lecaudey, L.A.; Schliewen, U.K.; Osinov, A.G.; Taylor, E.B.; Bernatchez, L.; Weiss, S.J. Inferring phylogenetic structure, hybridization and divergence times within Salmoninae (Teleostei: Salmonidae) using RAD-sequencing. Mol. Phys. Evol. 2018, 124, 82-99. [CrossRef] [PubMed]

123. Plötner, J.; Uzzell, T.; Beerli, P.; Spolsky, C.; Ohst, T.; Litvinchuk, S.N.; Guex, G.-D.; Reyer, H.-U.; Hotz, H. Widespread unidirectional transfer of mitochondrial DNA: A case in western Palaearctic water frogs. J. Evol. Biol. 2008, 21, 668-681. [CrossRef]

124. Powell, J.R. Interspecific cytoplasmic gene flow in the absence of nuclear gene flow: Evidence from Drosophila. Proc. Natl. Acad. Sci. USA 1983, 80, 492-495. [CrossRef] [PubMed]

125. Takahata, N.; Slatkin, M. Mitochondrial gene flow. Proc. Nat. Acad. Sci. USA 1984, 81, 1764-1767. [CrossRef]

126. Birky, C.W., Jr. Species Detection and Identification in Sexual Organisms Using Population Genetic Theory and DNA Sequences. PLoS ONE 2013, 8, e52544. [CrossRef]

127. Hedges, S.B.; Marin, J.; Suleski, M.; Paymer, M.; Kumar, S. Tree of Life Reveals Clock-Like Speciation and Diversification. Mol. Biol. Evol. 2015, 32, 835-845. [CrossRef]

128. Redin, A.D.; Kartavtsev, Y.P. Phylogenetic relationships of flounders from the family Pleuronectidae (Ostichties: Pleuronectiformes) based on 16S rRNA gene. Russ. J. Genet. 2021, 57, 348-360. [CrossRef]

129. Hall, B. Phylogenetic Trees Made Easy: A How-To Manual for Molecular Biologists, 4th ed.; Sinauer Associates: Sunderland, MA, USA, 2011; p. 282.

130. Miya, M.; Takeshima, H.; Endo, H.; Ishiguro, N.B.; Inoue, J.G.; Mukai, T.; Satoh, T.P.; Yamaguchi, M.; Kawaguchi, A.; Mabuchi, K.; et al. Major Patterns of Higher Teleostean Phylogenies: A New Perspective Based on 100 complete mitochondrial DNA sequences. Mol. Phylogenet. Evol. 2003, 26, 121-138. [CrossRef] 
131. Kartavtsev, Y.P.; Sharina, S.N.; Saitoh, K.; Imoto, J.M.; Hanzawa, N.; Redin, A.D. Phylogenetic relationships of Russian Far Eastern flatfish (Pleuronectiformes, Pleuronectidae) based on two mitochondrial gene sequences, Co- 1 and Cyt-b, with inferences in order phylogeny using complete mitogenome data. Mitochodrial DNA 2016, 27, 667-678. [CrossRef] [PubMed]

132. Imoto, J.M.; Saitoh, K.; Sasaki, T.; Yonezawa, T.; Adachi, J.; Kartavtsev, Y.P.; Miya, M.; Nishida, M.; Hanzawa, N. Phylogeny and biogeography of highly diverged freshwater fish species (Leuciscinae, Cyprinidae, Teleostei) inferred from mitochondrial genome analysis. Gene 2013, 514, 112-124. [CrossRef]

133. Berendzen, P.B.; Dimmick, W.W. Phylogenetic relationships of Pleuronectiformes based on molecular evidence. Copeia 2002, 3, 642-652. [CrossRef]

134. Pardo, B.G.; Machordom, A.; Foresti, F.; Porto-Foresti, F.; Azevedo, M.F.C.; Bañón, R.; Sanchez, L.; Martinez, P. Phylogenetic analysis of flatfish (Order Pleuronectiformes) based on mitochondrial 16s rDNA sequences. Sci. Mar. 2005, 69, 531-543. [CrossRef]

135. Saitoh, K.; Miya, M.; Nishida, M. Mitochondrial genomics of ostariophysan fishes: Perspectives on phylogeny and biogeography. J. Mol. Evol. 2003, 56, 464-472. [CrossRef]

136. Mayden, R.L.; Chen, W.-J.; Bart, H.L.; Doosey, M.H.; Simons, A.M.; Tang, K.L.; Wood, R.M.; Agnew, M.K.; Yang, L.; Hirt, M.V.; et al. Reconstructing the phylogenetic relationships of the earth's most diverse clade of freshwater fishes-Order Cypriniformes (Actinopterygii: Ostariophysi): A case study using multiple nuclear loci and the mitochondrial genome. Mol. Phylogenet. Evol. 2009, 51, 500-514. [CrossRef] [PubMed]

137. Betancur-R, R.; Orti, G. Molecular evidence for the monophyly of flatfishes (Carangimorpharia: Pleuronectiformes). Mol. Phylogenet. Evol. 2014, 73, 18-22. [CrossRef] [PubMed]

138. Vinnikov, K.A.; Thomson, R.C.; Munroe, T.A. Revised classification of the righteye flounders (Teleostei: Pleuronectidae) based on multilocus phylogeny with complete taxon sampling. Mol. Phylogenet. Evol. 2018, 125, 147-162. [CrossRef] [PubMed]

139. Bringloe, T.T.; Cottenie, K.; Martin, G.K.; Adamowicz, S.J. The importance of taxonomic resolution for additive beta diversity as revealed through DNA barcoding. Genome 2016, 59, 1130-1140. [CrossRef]

140. Zhang, J.; Kapli, P.; Pavlidis, P.; Stamatakis, A. A general species delimitation method with applications to phylogenetic placements. Bioinformatics 2013, 29, 2869-2876. [CrossRef]

141. Fujisawa, T.; Barraclough, T.G. Delimiting Species Using Single-Locus Data and the Generalized Mixed Yule Coalescent Approach: A Revised Method and Evaluation on Simulated Data Sets. Syst. Biol. 2013, 62, 707-724. [CrossRef] [PubMed]

142. Joly, S. JML: Testing hybridization from species trees. Mol. Ecol. Resour. 2012, 12, 179-184. [CrossRef] [PubMed]

143. Kartavtsev, Y.P.; Park, T.-J.; Lee, J.-S.; Vinnikov, K.A.; Ivankov, V.N.; Sharina, S.N.; Ponomarev, A.S. Phylogenetic inferences introduced on cytochrome $\mathrm{b}$ gene sequences data for six flatfish species (Teleostei, Pleuronectidae) and species synonymy between representatives of genera Pseudopleuronectes and Hippoglossoides from far eastern seas. Russ. J. Genet. 2008, 44, 451-458. [CrossRef]

144. Bayne, B.L.; Ahrens, M.J.; Allen, S.K.; D’Auriac, M.A.; Backeljau, T.; Beninger, P.; Bohn, R.; Boudry, P.; Davis, J.; Green, T.; et al. The Proposed Dropping of the Genus Crassostrea for All Pacific Cupped Oysters and Its Replacement by a New Genus Magallana: A Dissenting View. J. Shellfish. Res. 2017, 36, 545-547. [CrossRef]

145. Wiens, J.J.; Kuczynski, C.A.; Stephens, P.R. Discordant mitochondrial and nuclear gene phylogenies in emydid turtles: Implications for speciation and conservation. Biol. J. Linn. Soc. 2010, 99, 445-461. [CrossRef]

146. Drummond, A.J.; Bouckaert, R.R. Bayesian Evolutionary Analysis with BEAST; Cambridge University Press: Cambridge, UK, 2015; pp. 98-125. [CrossRef]

147. Bravo, G.A.; Antonelli, A.; Bacon, C.D.; Bartoszek, K.; Blom, M.P.K.; Huynh, S.; Jones, G.; Knowles, L.L.; Lamichhaney, S.; Marcussen, T.; et al. Embracing heterogeneity: Coalescing the tree of life and the future of phylogenomics. PeerJ 2019, 21, 1-60. [CrossRef]

148. Steinke, D.; Zemlak, T.S.; Boutillier, J.A.; Hebert, P.D.N. DNA barcoding of Pacific Canada's fishes. Mar. Biol. 2009, 156, $2641-2647$. [CrossRef]

149. Turanov, S.; Kartavtsev, Y.P.; Lipinsky, V.V.; Zemnukhov, V.V.; Balanov, A.A.; Lee, Y.-H.; Jeong, D. DNA-barcoding of perch-like fishes (Actinopterygii: Perciformes) from far-eastern seas of Russia with taxonomic remarks for some groups. Mitochondrial DNA 2014, 27, 1-22. [CrossRef]

150. McCusker, M.R.; Denti, D.; Van Guelpen, L.; Kenchington, E.; Bentzen, P. Barcoding Atlantic Canada's commonly encountered marine fishes. Mol. Ecol. Resour. 2013, 13, 177-188. [CrossRef]

151. Sharina, S.N.; Kartavtsev, Y.P. Phylogenetic and taxonomic analysis of flatfish species (Teleostei, Pleuronectiformes) inferred from the primary nucleotide sequence of cytochrome oxidase 1 gene (Co-1). Russ. J. Genet. 2010, 46, 356-361. [CrossRef]

152. Roje, D.M. Incorporating molecular phylogenetics with larval morphology while mitigating the effects of substitution saturation on phylogeny estimation: A new hypothesis of relationships for the flatfish family Pleuronectidae (Percomorpha: Pleuronectiformes). J. Mol. Phys. Evol. 2010, 56, 586-600. [CrossRef]

153. Kijewska, A.; Burzyński, A.; Wenne, R. Molecular identification of European flounder (Platichthys flesus) and its hybrids with European plaice (Pleuronectes platessa). ICES J. Mar. Sci. 2009, 66, 902-906. [CrossRef]

154. Zbawicka, M.; Gardner, J.P.A.; Wenne, R. Cryptic diversity in smooth-shelled mussels on Southern Ocean islands: Connectivity, hybridisation and a marine invasion. Front. Zoöl. 2019, 16, 1-12. [CrossRef]

155. Hanzawa, N.; Taniguchi, N.; Shinzawa, H. Genetic markers of the artificial hybrids between Tribolodon hakonensis and T. sp. (Ukeguchi-Ugui). Otsuchi Mar. Res. Cent. Rep. Univ. Tokyo 1984, 10, 11-17. 
156. Miya, M.; Saitoh, K.; Wood, R.; Nishida, M.; Mayden, R.L. New primers for amplifying and sequencing the mitochondrial ND4/ND5 gene region of the Cypriniformes (Actinopterygii: Ostariophysi). Ichthyol. Res. 2006, 53, 75-81. [CrossRef]

157. Saitoh, K.; Sado, T.; Mayden, R.L.; Hanzawa, N.; Nakamura, K.; Nishida, M.; Miya, M. Mitogenomic Evolution and Interrelationships of the Cypriniformes (Actinopterygii: Ostariophysi): The First Evidence Toward Resolution of Higher-Level Relationships of the World's Largest Freshwater Fish Clade Based on 59 Whole Mitogenome Sequences. J. Mol. Evol. 2006, 63, 826-841. [CrossRef] [PubMed]

158. Saitoh, K.; Chen, W.-J.; Mayden, R.L. Extensive hybridization and tetrapolyploidy in spined loach fish. Mol. Phylogenet. Evol. 2010, 56, 1001-1010. [CrossRef] [PubMed]

159. Sakai, H.; Ito, Y.; Shedko, S.V.; Safronov, S.N.; Frolov, S.V.; Chereshnev, I.A.; Jeon, S.-R.; Goto, A. Phylogenetic and Taxonomic Relationships of Northern Far Eastern Phoxinin Minnows, Phoxinus and Rhynchocypris (Pisces, Cyprinidae), as Inferred from Allozyme and Mitochondrial 16S rRNA Sequence Analyses. Zoöl. Sci. 2006, 23, 323-331. [CrossRef]

160. Semina, A.V.; Polyakova, N.E.; Brykov, V.A. Genetic analysis identifies a cryptic species of Far Eastern daces of the genus Tribolodon. Dokl. Biol. Sci. 2006, 407, 173-175. [CrossRef]

161. Sasaki, T.; Kartavtsev, Y.P.; Chiba, S.N.; Uematsu, T.; Sviridov, V.V.; Hanzawa, N. Genetic divergence and phylogenetic independence of Far Eastern species in subfamily Leuciscinae (Pisces: Cyprinidae) inferred from mitochondrial DNA analyses. Genes Genet. Syst. 2007, 82, 329-340. [CrossRef]

162. Yang, L.; Sado, T.; Hirt, M.V.; Pasco-Viel, E.; Arunachalam, M.; Li, J.; Wang, X.; Freyhof, J.; Saitoh, K.; Simons, A.M.; et al. Phylogeny and polyploidy: Resolving the classification of cyprinine fishes (Teleostei: Cypriniformes). Mol. Phylogenet. Evol. 2015, 85, 97-116. [CrossRef] [PubMed]

163. Śmietanka, B.; Burzyński, A.; Hummel, H.; Wenne, R. Glacial history of the European marine mussels Mytilus, inferred from distribution of mitochondrial DNA lineages. Heredity 2014, 113, 250-258. [CrossRef] [PubMed]

164. Zbawicka, M.; Wenne, R.; Burzyński, A. Mitogenomics of recombinant mitochondrial genomes of Baltic Sea Mytilus mussels. Mol. Genet. Genom. 2014, 289, 1275-1287. [CrossRef] [PubMed]

165. Zbawicka, M.; Trucco, M.I.; Wenne, R. Single nucleotide polymorphisms in native South American Atlantic coast populations of smooth shelled mussels: Hybridization with invasive European Mytilus galloprovincialis. Genet. Sel. Evol. 2018, 50, 1-14. [CrossRef]

166. Wenne, R.; Bach, L.; Zbawicka, M.; Strand, J.; McDonald, J.H. A first report on coexistence and hybridization of Mytilus trossulus and M. edulis mussels in Greenland. Polar Biol. 2016, 39, 343-355. [CrossRef]

167. Pereira, L.H.G.; Hanner, R.; Foresti, F.; Oliveira, C. Can DNA barcoding accurately discriminate megadiverse Neotropical freshwater fish fauna? BMC Genet. 2013, 14, 20. [CrossRef]

168. Mayr, E. Zoological Species and Evolution; Mir Publ.: Mowcow, Russia, 1968; p. 398. (In Russian)

169. Simpson, G.G. Organisms and molecules in evolution. Science 1964, 146, 1535-1538. [CrossRef]

170. Simpson, G.G. Principles of Animal Taxonomy. The Species and Lower Categories; Columbia Univ. Press: New York, NY, USA, 1961.

171. Paterson, H.E.H. More evidence against speciation by reinforcement. S. Afr. J. Sci. 1978, 74, 369-371.

172. Paterson, H.E.H. The recognition concept of species. In Species and Speciation; Vrba, E.S., Ed.; Transvaal Museum Monograf: Pretoria, South Africa, 1985; pp. 21-29.

173. Wiley, E.O. Phylogenetics. In The Theory and Practice of Phylogenetic Systematics; John Wiley and Sons: New York, NY, USA, 1981.

174. Cracraft, J. Species concepts and speciation analysis. Curr. Ornithol. 1983, 1, 159-187.

175. Van Valen, L. Ecological species, multispecies, and oaks. Taxon 1976, 25, 233-239. [CrossRef]

176. Dobzhansky, T. Evolution, Genetics and Man; John Wiley \& Sons. Inc.: New York, NY, USA; Chapman \& Hall, Limited: London, UK, 1955; p. 398.

177. Edwards, S.V.; Xi, Z.; Janke, A.; Faircloth, B.C.; McCormack, J.E.; Glenn, T.C.; Zhong, B.; Wu, S.; Lemmon, E.M.; Lemmon, A.R.; et al. Implementing and testing the multispecies coalescent model: A valuable paradigm for phylogenomics. Mol. Phylogenetics Evol. 2016, 94, 447-462. [CrossRef]

178. Martsikalis, P.V.; Gkafas, G.A.; Palaiokostas, C.; Exadactylos, A. Genomics Era on Breeding Aquaculture Stocks. In Organic Aquaculture; Springer Science and Business Media LLC: Berlin, Germany, 2019; pp. 65-77.

179. Avise, J.C.; Aquadro, C.F. A Comparative Summary of Genetic Distances in the Vertebrates. Evol. Biol. 1982, 15, 151-185. [CrossRef]

180. Ladoukakis, E.D.; Zouros, E. Evolution and inheritance of animal mitochondrial DNA: Rules and exceptions. J. Biol. Res. 2017, 24, 1-7. [CrossRef] [PubMed]

181. Schwartz, J.H. Evolution, systematics, and the unnatural history of mitochondrial DNA. Mitochondrial DNA Part A 2021, 32, 126-151. [CrossRef]

182. Balakirev, E.S.; Ayala, F.J. Pseudogenes: Are they "junk" or functional DNA? Annu. Rev. Genet. 2003, 37, 123-151. [CrossRef] [PubMed] 